\title{
Temporal and spatial heterogeneity in milk and immune-related gene expression during mammary gland involution in dairy cows
}

\author{
K. Singh, ${ }^{* 1,2}$ C. V. C. Phyn, ${ }^{*} \dagger$ M. Reinsch, ${ }^{* 3}$ J. M. Dobson,,${ }^{* 4}$ K. Oden, ${ }^{* 5}$ S. R. Davis, ${ }^{* 6}$ K. Stelwagen, ${ }^{* 7}$ \\ H. V. Henderson, ${ }^{*}$ and A. J. Molenaar*1 \\ *AgResearch Ltd., Ruakura Research Centre, Private Bag 3123, Hamilton 3214, New Zealand \\ †DairyNZ Ltd., Hamilton 3286, New Zealand
}

\begin{abstract}
The aim of this study was to investigate heterogeneity in tissue morphology, milk protein and immune-related gene expression, and apoptosis of epithelial cells in the lactating and involuting mammary glands of the dairy cow. Mammary tissue from different regions of the gland (alveolar, cisternal, and peripheral) was collected postmortem from nonpregnant, pasture-fed, HolsteinFriesian primiparous cows in mid-lactation that were killed at different time points postmilking: 0, 6, 12, 18, 24,36 , and $72 \mathrm{~h}$ ( $\mathrm{n}=6$ per time point). The CSN1NS1 and $L A L B A$ mRNA was decreased in alveolar, cisternal, and peripheral tissue by 12 to $36 \mathrm{~h}$ postmilking. In contrast, lactoferrin $(L F)$ and mammary serum amyloid A3 (M-SAA3) mRNA was increased in these regions by 36 to $72 \mathrm{~h}$. During lactation, more variability was present in gene expression in alveolar tissue between cows and between quarters within a cow, than within quarters. Histological analysis indicated the alveolar tissue from lactating cows was mostly uniform in structure; however, in situ hybridization indicated that although most of the alveolar tissue expressed milk proteins, the level of expression varied within and between alveoli. This heterogeneity became more pronounced with involution and with increasing regions of alveoli expressing lactoferrin, indicating that alveoli enter involution asynchronously. The peripheral and
\end{abstract}

\footnotetext{
Received January 9, 2017.

Accepted May 5, 2017.

${ }^{1}$ Corresponding authors: kuljeet.singhparhar@outlook.com and adrian.molenaar@agresearch.co.nz

${ }^{2}$ Present address: Science Consultancy, Hamilton 3200, New Zealand.

${ }^{3}$ Present address: Department of Experimental Pharmacology and Toxicology, University Medical Centre Hamburg-Eppendorf, Martinistraße 52, 20246 Hamburg, Germany.

${ }^{4}$ Present address: Carne Technologies Ltd., Cambridge 3450, New Zealand.

${ }^{5}$ Present address: ManukaMed Ltd., Hamilton 3214, New Zealand.

${ }^{6}$ Present address: LIC, Hamilton 3286, New Zealand.

${ }^{7}$ SciLactis Ltd., Waikato Innovation Park, Ruakura Rd., Hamilton 3214, New Zealand.
}

cisternal tissue had more variability in gene expression between cows compared with the alveolar tissue. The $M-S A A 3$ signal was more intense in the cisternal tissue and less intense than the peripheral compartment compared with $L F$ particularly in the earlier time points. In addition, between cows within the later time points, differences were observed in tissue morphology, the levels of milk protein and immune-related gene expression, and phosphorylated signal transducer and activator of transcription (STAT) 5-P and STAT3-P proteins, and degree of apoptosis, indicating that involution of the mammary gland occurs at different rates between cows. Understanding the mechanisms initiating the process of involution of the mammary gland provides an opportunity for enhancing milk production of the dairy cow. Key words: dairy cow, lactation, mammary involution, apoptosis

\section{INTRODUCTION}

In dairy cows, the number and activity of the mammary epithelial cells (MEC) are the key factors determining milk production. The gradual decline in milk production that occurs following peak lactation is due to a steady decrease in MEC number via apoptosis (Capuco et al., 2001). The cessation of milk removal also initiates the involution process and increases cell death (Wilde et al., 1997; Singh et al., 2005), as well as increasing cell proliferation (Sorensen et al., 2006; Mallah et al., 2013). Initially, the physiological changes that occur following milk accumulation include distension of the mammary gland, a decline in the rate of milk secretion, increased tight-junction permeability and lactose efflux, and an inflammatory response (Hurley, 1989; Davis et al., 1999). The morphological changes that occur include a reduction in luminal alveolar area and an increase in the stromal area in the mammary gland (Holst et al., 1987; Hurley, 1989).

Widespread changes are also present at the molecular level (Singh et al., 2008), which include a decline in milk protein gene expression (Hurley, 1989; Good- 
man and Schanbacher, 1991; Singh et al., 2008) and cell survival signals (Singh et al., 2005). This is followed by an increase in multiple protective responses to oxidative stress and numerous immunomodulatory factors (Singh et al., 2008), including lactoferrin $(L F)$ (Hurley, 1989; Goodman and Schanbacher, 1991) and mammary serum amyloid A3 (M-SAA3; Molenaar et al., 2009). Furthermore, the reciprocal activation (phosphorylation) of signal transducer and activator of transcription factors (STAT) 5 and STAT3 has been demonstrated in bovine mammary glands. This is associated with milk protein gene expression and the proportion of tissue with a lactating phenotype during early involution (Singh et al., 2016) and in response to altered milking frequency (Murney et al., 2015). The activation of STAT5 is a survival signal in MEC, suppressing STAT3-mediated apoptosis (Clarkson et al., 2006). At the onset of involution, prolactin signaling is downregulated via the inactivation of STAT5 (SchmittNey et al., 1992; Philp et al., 1996), and pro-apoptotic STAT3 is activated (Chapman et al., 1999; Kritikou et al., 2003), which then activates acute phase response and inflammation-related genes (Clarkson et al., 2004) and is also linked to survival signaling (Chapman et al., 1999).

Interestingly, analysis of tissue sections during lactation in the beef cow and sheep mammary gland indicate the presence of a heterogeneous population of alveoli (Molenaar et al., 1992, 1996a). That is, the majority of the alveoli are functionally active and secrete milk; however, small regions of alveoli do not express lactation-associated milk protein genes but contain numerous fat-containing vesicles (vesicle-engorged alveoli; VEA), indicative of involution. Thus, milk protein genes, such as LALBA and CSN1S1, may be either switched on or off between adjacent alveoli (Molenaar et al., 1992; Farr et al., 1996), especially in the more heterogeneous peripheral alveolar tissue compared with the central secretory alveolar tissue. In addition, $L F$ is expressed in alveoli where there is no expression of major milk proteins. These alveoli are considered to be quiescent and in the engorged state, and it is proposed that all MEC pass through the quiescent phase before becoming senescent (Davis et al., 1999).

The diversity in milk protein gene expression was also observed during involution of the mammary gland in both beef cows and sheep (Molenaar et al., 1992). The majority of alveoli have an involuting phenotype with small regions expressing milk protein genes. In sheep, there were local regions of alveoli with an inverse relationship between MEC apoptosis and milk secretory activity (Molenaar et al., 1996b), and also in cows and goats, MEC apoptosis may be localized to regressing alveoli (Wilde et al., 1997; Li et al., 1999).
Heterogeneity in tissue morphology and gene expression of the lactating and involuting mammary gland in dairy cows has not been studied extensively. If it occurs to any extent this local variation could result in sub-optimal dairy production and its potential manipulation offers a way of increasing production. This study examines variation in the mRNA expression of 2 milk protein genes ( $L A L B A$ and CSN1S1), 2 involution/defense-associated genes ( $L F$ and $M-S A A 3$ ), and the STAT transcription factors during lactation and in relation to apoptosis during mammary involution of dairy cows.

\section{Cows}

Animal experimentation was conducted in compliance with the rules and guidelines of the Ruakura Animal Ethics Committee (Hamilton, New Zealand). Mammary alveolar tissue samples were used from a subset obtained from an animal experiment described previously (Singh et al., 2016). Briefly, involution of the bovine mammary gland was induced by abrupt termination of milking in 42 nonpregnant Holstein-Friesian dairy cows at, or close to, their peak milk production and before mating in mid-lactation (average DIM, 89.1 \pm 2.2 ). The primiparous cows were solely pasture-fed, milked twice daily from parturition, and had an average daily milk yield of $14.3 \pm 0.3 \mathrm{~kg} / \mathrm{cow}$. The average SCC in composite (4 quarters) milk before the termination of milking was $159,000 \pm 20,000$ cells $/ \mathrm{mL}$. The cows were slaughtered at the Ruakura Abattoir (Hamilton, NZ) using standard commercial procedures (electrical stunning followed by exsanguination) at $0,6,12,18$, 24,36 , and $72 \mathrm{~h}$ ( $\mathrm{n}=6$ per time point) after the last milking.

Mammary alveolar tissue (approximately $30 \mathrm{~g}$ ) was collected from the middle of the upper one-third of the gland of a rear quarter of each animal, snap-frozen in liquid nitrogen, and stored at $-80^{\circ} \mathrm{C}$ until required for subsequent RNA and protein extraction. Additional samples of alveolar tissue (10 to $30 \mathrm{~g}$ ) were taken from 5 different random but distributed sites within each of the 4 udder quarters of cows $(n=3$ cows, 60 samples in total) in the 6-h group to examine local variation in gene expression. Samples of peripheral tissue (referred to as capsular tissue by Farr et al., 1996) were also collected and snap frozen in liquid nitrogen and stored at $-80^{\circ} \mathrm{C}$ until required for subsequent RNA extraction. Peripheral tissue is a 1 to $2 \mathrm{~cm}$ band of subcutaneous secretory mammary tissue surrounding the majority of the secretory alveolar tissue facing the skin and cisternal tissue, located between the teat and the secretory alveolar tissue. 
Approximately 0.5-to-1.0-cm-thick samples of alveolar tissue (10 g) corresponding to the tissues collected for frozen storage were also obtained from each animal for histological, in situ hybridization and in situ endlabeling (ISEL) analysis and immediately fixed in $4 \%$ phosphate-buffered paraformaldehyde for $24 \mathrm{~h}$. Slices $(\sim 25 \times 30 \times 2 \mathrm{~mm})$ were cut from formalin-fixed alveolar tissue samples, processed, embedded in paramat wax (BDH Laboratory Supplies, Dorset, UK) and serial sections $(8 \mu \mathrm{m})$ of each sample were cut and mounted onto polysine glass slides (BioLab Scientific, Auckland, New Zealand) as described previously (Singh et al., 2005). In addition, a further subset of mammary tissue samples obtained from the animal experiment described previously (Singh et al., 2016) were also analyzed using in situ hybridization. This subset included samples collected $192 \mathrm{~h}$ postmilking from a separate cohort of animals $(\mathrm{n}=6)$ in the following lactation season. This time point was analyzed because it showed increased levels of $L F$ compared with $6 \mathrm{~h}$ postmilking, measured by real-time RT-PCR and western analysis (Singh et al., 2008).

\section{Isolation of Total RNA from Mammary Tissue}

Total RNA was isolated from approximately 300 mg of pulverized frozen mammary tissue using TRIzol reagent (Invitrogen, Carlsbad, CA) following the manufacturer's protocol and quantified by measuring its absorbance at $260 \mathrm{~nm}$. To verify integrity, cellular RNA $(2.5 \mu \mathrm{g})$ was electrophoresed in a $1.2 \%$ agarose gel and stained with ethidium bromide. Cellular RNA that had intact $28 \mathrm{~S}$ and $18 \mathrm{~S}$ ribosomal bands was used in subsequent analyses. Isolated RNA was stored at $-80^{\circ} \mathrm{C}$ until required.

\section{Northern Blot Analysis}

The RNA $(2.5 \mu \mathrm{g})$ was denatured with $50 \%$ formamide $/ 7 \%$ formaldehyde (vol/vol) and subjected to electrophoresis in 2 duplicate $1.2 \%$ agarose/formaldehyde gels. After overnight capillary transfer to Hybond N membranes (GE Healthcare Life Sciences, Auckland, New Zealand), the RNA was UV cross-linked and stained with methylene blue to confirm equal loading (Herrin and Schmidt, 1988). The density of the 28S ribosomal RNA band in the membrane was quantified using a GS-800 Calibrated Densitometer (Bio-Rad Laboratories, Hercules, CA) and Quantity One software (Bio-Rad Laboratories). The DNA probes for Northern blotting were a 700-bp bovine $L A L B A$ cDNA (Hurley and Schuler, 1987), GenBank accession no. M18780; a 761-bp EcoRI/PstI fragment of the bovine CSN1S1 clone pC184 (Stewart et al., 1984); a 704-bp $5^{\prime}$ fragment of a bovine $L F$ cDNA kindly provided by J. Tweedie (Mead and Tweedie, 1990), GenBank accession no. X54801; and the full-length cDNA for $M-S A A 3$, GenBank accession no. AY943216, isolated from an in-house cDNA library made from mammary tissue of a lactating cow. The membranes were incubated overnight at $65^{\circ} \mathrm{C}$ in a phosphate buffer (Church and Gilbert, 1984) containing the probes that had been generated using a random primer labeling kit (Invitrogen) and $\left[\alpha^{32} \mathrm{P}\right] \mathrm{dATP}$ (GE Healthcare Life Sciences). After hybridization, the membranes were washed to a stringency of $1 \times \mathrm{SSC}\left(150 \mathrm{~m} M \mathrm{NaCl}, 15 \mathrm{~m} M \mathrm{Na}_{3}\right.$ citrate $/ 0.1 \times \mathrm{SDS}$ at $65^{\circ} \mathrm{C}$ ) to remove the unhybridized probe. The signal was detected either with XAR-5 film (Kodak, Rochester, NY) or a storage phosphor HD screen (Kodak) for intervals ranging from $4 \mathrm{~h}$ to $5 \mathrm{~d}$ depending on the signal intensity and the density for each mRNA band analyzed as described above. The membranes were first incubated with either the $L F$ or $M-S A A 3$ probe and, after the signals were captured, they were stripped twice using the Hot $0.1 \%$ SDS procedure (Amersham HybondN+ manual), checked to ensure there was no remaining signal, and reincubated with either the CSN1S1 or the LALBA probe. The mRNA abundance was normalized by the density of the $28 \mathrm{~S}$ rRNA band to correct for variation in sample loading and gel to membrane transfer.

\section{In Situ Hybridization}

For histological analysis, hematoxylin-and-eosinstained sections of alveolar mammary tissue from each time point $(\mathrm{n}=6)$ were examined and representative serial sections were chosen for in situ hybridization studies. In situ hybridization was performed on serial sections of mammary alveolar tissue, as described previously (Singh et al., 2005). The cDNA for the abovedescribed CSN1S1 and $L F$ probes were inserted into pGEM vectors (Promega Corporation, Madison, WI) as described previously (Molenaar et al., 1992).

The nucleotide sequence of the bovine CSN1S1 probe was as follows: AGTAGGTTTAA A TA G C T T G GA A G C A A A A T C T G CCATCACCTTGATCATCAACCCAGCTTGCTGCTTCTTCCCAGTCTTGGGTTCAAGATCTTGACAACCATGAAACTTCTCATCCTTACCTGTCTTGTGGCTGTTGCTCTTGCTAGGCCTAAACATCCTATCAAGCACCAAGGACTCCCTCAAGAAGTCCTCAATGAAAATTTACTCAGGT T T T T T G T G GCACC T T T TCCAGAAGTGTTTGGAAAGGAGAAGGTCAATGAACTGAGCAAGGATATTGGGAGTGAATCAACTGAGGATCAAGCCATGGA A GATAT TAA GCAAATGGAAGCTGAAAGCATT TCGTCAAGTGAG- 
GAAATTGTTCCCAATAGTGTTGAGCAGAAGCACATTCAAAAGGAAGATGTGCCCTCTGAGCGTTACCTGGGTTATCTGGAACAGCTTCTCAGACTGAAAAAATACAAAGTACCCCAGCTGGAAATTGTTCCCAATAGTGCTGAGGAACGACTTCACAGTATGAAAGAGGGAATCCATGCCCAACAGAAAGAACCTATGATAGGAGTGAATCAGGAACTGGCCTACTTCTACCCTGAGCTTTTCAGACAATTCTACCAGCTGGATGCCTATCCATCTGGTGCCTGGTATTACGTTCCACTAGGCACACAATACACTGATGCCCCATCATTCTCTGACATCCCTAATCCTATTGGCTCTGAGAACAGTGAAAAGACTACTATGCCACTGTGGTGAGGAGTCAAGTGAATTC.

The nucleotide sequence of the bovine lactoferrin probe was as follows: TCACCTGTGTGAGGAGGGCCTTTGCCTTGGAATGTATCCGGGCCATCGCGGAGAAAAAGGCGGATGCTGTGACCCTGGATGGTGGCATGGTGTTTGAGGCGTGCCGGGACCCCTACAAACTGCGGCCAGTAGCAGCAGAGATCTATGGGACGAAAGAGTCTCCCCAAACCCACTATTATGCTGTGGCCGTCGTGAAGAAGGGCAGCAACTTTCAGCTGGACCAGCTGCAAGGCCGGAAGTCCTGCCATACGGGCCTTGGCAGGTCCGCTGGGTGGATCATCCCTATGGGAATCCTT C G C C C G TA C T T GA G C T G GA C A GA G T CACTCGAGCCCCTCCAGGGAGCTGTGGCTAAATTCTTCTCTGCCAGCTGTGTTCCCTGCATTGATAGACAAGCATACCCCAACCTGTGTCAACTGTGCAAGGGGGAGGGGGAGAACCAGTGTGCCTGCTCCTCCCGGGAACCATACTTCGGTTATTCTGGTGCCTTCAAGTGTCTGCAGGA C GGGGCTGGA GA C G T G GCT T T T G TTAAAGAGACGACAGTGTTTGAGAACT TGCCAGAGAAGGCTGACAGGGACCAGTATGAGCTTCTCTGCCTGAACAACAGTCGGGCGCCAGTGGATGCGTTCAAGGAGTGCCACCTGGCCCAGGTCCCTTCTCATGCTGTCGTGGCCCGAAGTGTGGATGGCAAGGAAGACTTGATCTGGAAGCTTCTCA.

The sense and antisense RNA were transcribed and labeled with digoxigenin-11-2'-deoxy-uridine-5'triphosphate (alkali stable, DIG-UTP, Roche Diagnostics, Auckland, New Zealand) to make RNA probes as described by the manufacturer. Sections were hybridized with 1 to $50 \mathrm{ng}$ of the purified labeling reaction, in 50 $\mu \mathrm{L}$ in Ultrahybe (Ambion, Life Technologies, Auckland, New Zealand) per $\mathrm{cm}^{2}$ of tissue section. The sections were washed as described and signal was visualized using anti-DIG IgG conjugated to alkaline phosphatase (Roche Diagnostics) using a solution containing 18.75 $\mathrm{mg} / \mathrm{mL}$ of nitro blue tetrazolium chloride and $9.4 \mathrm{mg} /$ $\mathrm{mL}$ of 5-bromom-4-chloro-3-indolyl phosphate (Roche) as substrate.

\section{Analysis of Apoptotic Nuclei}

In situ end-labeling of fragmented DNA was performed at each of the time points and quantitative analysis of cells with fragmented DNA (i.e., ISEL nuclei) in the histological sections was carried out using light microscopy (Olympus BH-2), as described previously (Singh et al., 2005). Ten randomly selected fields (100× magnification) were photographed per sample and the number of ISEL nuclei and alveoli were counted using the mark and count analysis tool in ImageJ (US National Institutes of Health, http://rsb.info.nih. gov/nih-image). Positive ISEL nuclei were identified as either located within the secretory epithelial layer or within the lumen of mammary alveoli. The value 1 was added to each count of ISEL nuclei per field followed by a correction for the number of alveoli per field. Data were $\log _{10}$-transformed.

\section{Western Blot Analysis}

Total homogenate and soluble protein fractions were isolated from mammary alveolar tissue and protein concentration determined as described previously (Singh et al., 2016). The Tyr 694-phosphorylated STAT5A/B [STAT5-P; 1:30,000, kindly provided by T. Wheeler, AgResearch Ltd., Hamilton, NZ (Wheeler et al., 2001)] protein was measured in the total homogenate fractions, and Tyr 705-phosphorylated STAT3 (STAT3-P; 1:10,000, sc-7993-R, Santa Cruz Biotechnology, Santa Cruz, CA) was measured in the soluble fractions as described previously (Singh et al., 2016). Duplicate gels were stained with Coomassie blue to indicate uniformity of loading per lane. Furthermore, the levels of nonphosphorylated STAT3 reported previously (Singh et al., 2016) did not change across the time-series, indicating differences in STAT5-P and STAT3-P are biological. The immunoreactive bands were visualized by enhanced chemiluminescence and then exposed to X-Omat AR film (Carestream Health Inc., Rochester, $\mathrm{NY}$ ) for 2 to $30 \mathrm{~min}$, depending on the protein of interest. Films were scanned using a densitometer (GS 800, Bio-Rad), and the densities of immunoreactive bands were determined using Quantity One software (Bio$\mathrm{Rad})$.

\section{Immunohistochemistry Analysis}

Immunohistochemistry analysis for STAT5-P and STAT3-P was conducted as described previously (Singh et al., 2016). To visualize positive MEC, slides were developed with 3,3'-diaminobenzidine tetrahydrochloride with additional nickel sulfate to produce a blue/ black precipitate and then counterstained in $0.5 \%$ eosin 
solution. To distinguish between labeled and unlabeled MEC nuclei, slides were stained in nuclear fast red for pink/red nuclei. Location and intensity of STAT5-P and STAT3-P protein signal were examined under $40 \times$, $100 \times, 200 \times$, and $400 \times$ magnification using a binocular microscope (Olympus Optical Co. Ltd., London, UK). Histological images were photographed using a Prog14 digital camera (Jenoptik GmbH, Jena, Germany) and PaintShopPro software, version 7.02 (Jasc Software Inc., Eden Prairie, MN).

\section{Statistical Analysis}

For Northern analysis across the time series, the differences between $\log _{10}$ normalized densitometry values were analyzed with ANOVA using Minitab (2003, Minitab Inc., State College, PA). The means for each group were expressed as the fold change \pm SEM relative to the 6 -h mean. The 6 -h time point was used in preference to the 0 - $\mathrm{h}$ time point because $0 \mathrm{~h}$ represents tissue taken after a 12-h milking interval (i.e., the regular milking interval immediately before the start of the experiment was $12 \mathrm{~h}$ ), whereas the 6 -h sample was the sample taken after the shortest milking interval. The variation in gene expression by cows, quarters within cows, and sites within quarter was estimated from a variance component analysis on the $\log _{10}$ normalized densitometry values using REML in GenStat (2011). The 3 variance components are presented as a percentage of the total variance. For ISEL analysis, the $\log _{10}$-transformed data were analyzed by ANOVA and data were expressed as the back-transformed mean (1+ ISEL nuclei) per alveolus. The least significant differences identify the means significantly different from each other.

\section{RESULTS}

\section{Temporal Changes and Heterogeneity in Milk Protein and Immune-Related Gene Expression in Mammary Gland During Involution}

The CSN1S1, LALBA, M-SAA3, and LF mRNA expression in alveolar, peripheral, and cisternal mammary tissue from cows during induced involution are presented in Figure 1. On average, milk protein mRNA levels decreased and immune-related genes increased during involution (Figure 1A).

In alveolar and peripheral tissue, CSN1S1 mRNA levels were downregulated by $24 \mathrm{~h}$ postmilking by 1.7 $(P<0.01)$ and 1.4 -fold $(P<0.05)$, respectively, compared with $6 \mathrm{~h}$ postmilking. In cisternal tissue, CSN1S1 mRNA levels were downregulated by $36 \mathrm{~h}$ postmilking by almost 3 -fold $(P<0.05)$, and the levels remained low in all 3 regions to $72 \mathrm{~h}$ postmilking compared with $6 \mathrm{~h}$ postmilking (Figure 1A).

The $L A L B A$ mRNA levels in the alveolar tissue were increased 1.3 -fold $(P<0.05)$ by 12 and $18 \mathrm{~h}$ postmilking, compared with $6 \mathrm{~h}$; however, they were then downregulated 1.5 -fold $(P<0.05)$ by $24 \mathrm{~h}$ postmilking and by almost 4 -fold $(P<0.001)$ by $72 \mathrm{~h}$ postmilking. In the peripheral tissue, the average $L A L B A \mathrm{mRNA}$ levels were downregulated by $12 \mathrm{~h}$ postmilking by almost 3 -fold $(P<0.01)$ and the levels remained low in all 3 regions to $72 \mathrm{~h}$ postmilking (Figure $1 \mathrm{~A}$ ).

Expression of $M$-SAA 3 and $L F$ mRNA was barely detectable in overnight autoradiography of alveolar tissue RNA until $72 \mathrm{~h}$ postmilking (Figure $1 \mathrm{~B}$ ), when average $M$-SAA3 mRNA levels were increased 3.6-fold $(P<$ 0.05 , Figure 1A). A 5 -d autoradiograph of $L F$ showed mRNA levels were increased $72 \mathrm{~h}$ postmilking by 2.1fold $(P<0.01$, Figure 1A). In cisternal tissue, both $L F$ $(P<0.001)$ and $M$-SAA3 $(P<0.01)$ mRNA levels were detected in the majority of samples at all time points (Figure 1B) and increased from $36 \mathrm{~h}$ postmilking, compared with $6 \mathrm{~h}$ postmilking. In peripheral tissue, $M$ $S A A 3 \mathrm{mRNA}$ levels were detectable in approximately one-third of the samples up to $24 \mathrm{~h}$ postmilking (Figure 1B), and detectable by 36 and $72 \mathrm{~h}$ postmilking in all samples (Figure 1B) with an average increase of over 25 -fold $(P<0.05$; Figure $1 \mathrm{~A})$.

Northern blot analysis (Figure 1B) indicated that in alveolar tissue, the decline in the expression of the milk protein genes, $L A L B A$ and $C S N 1 S 1$, by $36 \mathrm{~h}$ was variable between animals within the same time point. This was particularly pronounced by $72 \mathrm{~h}$ postmilking when $L F$ mRNA and $M-S A A 3$ expression was also detectable and variable between animals. Across all the 0 to $72 \mathrm{~h}$ time points, peripheral and cisternal tissue had more variation between cows in expression of $L A L B A$, $C S N 1 S 1, L F$, and M-SAA3 compared with the alveolar tissue (Figure 1B). There was also variation between the expression of $M-S A A 3$ and $L F$ in the peripheral versus the cisternal compartments. The $M$-SAA3 signal was more intense in the cisternal tissue and less intense in the peripheral compartment compared with $L F$, particularly in the earlier time points. Longer autoradiography emphasized that the expression of $L F$ in the cisternal compartment was relatively constant regardless of the time point (Figure 1B).

\section{Heterogeneity in Morphology of the Mammary Gland During Involution}

The changes in morphology were related to relative changes in LALBA mRNA expression during mammary engorgement. Histological analysis of tissue indicated that although there was very little difference in 
the morphology of the tissue between cows at the early time points (described previously, Singh et al., 2005), considerable variation was present in tissue structure between cows by 36 and $72 \mathrm{~h}$ postmilking (Figure 2). At these later time points, mammary tissue from cows with high relative $L A L B A \mathrm{mRNA}$ expression had a similar morphology to tissue from lactating cows (6 $\mathrm{h}$ postmilking), which was characterized by large uniform areas of moderately sized open alveoli surrounded by cuboidal MEC with only a small amount of interalveolar stromal tissue visible (Figures 2A, 2B, 2G, and $2 \mathrm{H}$ ). Samples with low relative $L A L B A$ mRNA expression (Figures 2E, 2F, 2K, and $2 \mathrm{~L}$ ) had an earlier response to involution than samples with moderate (Figures 2C, 2D, 2I, and 2J) or high relative $L A L B A$ expression (Figures 2A, 2B, 2G, and $2 \mathrm{H}$ ). Heterogeneity was also observed within the tissue samples, with lobules of involuting alveoli in some areas, whereas in others alveoli retained the appearance of lactation. This relationship was more apparent by $72 \mathrm{~h}$ postmilking. Compared with mammary samples with high relative $L A L B A$ expression, mammary tissue with a moderate $L A L B A$ mRNA level had more heterogeneity, with areas of open, stretched, lactating alveoli, abundance of large vesicles within MEC and alveolar lumens, and collapsed VEA. This was also apparent in mammary tissue with low relative $L A L B A$ expression at $36 \mathrm{~h}$ postmilking (Figures $2 \mathrm{E}$ and $2 \mathrm{~F}$ ). However, at $72 \mathrm{~h}$ postmilking, the tissue with low relative $L A L B A$ expression exhibited a nonlactating phenotype and was characterized by collapsed alveoli, abundance of large vesicles within MEC and alveolar lumens, thickened areas of stromal tissue between alveoli, and broad bands of supportive connective tissue containing adipocytes (Figures $2 \mathrm{E}, 2 \mathrm{~F}, 2 \mathrm{~K}$, and $2 \mathrm{~L}$ ). A large number of leukocytes were present inside the alveolar lumen of highly involuted tissue adipocytes (Figures 2E, 2F, $2 \mathrm{~K}$, and $2 \mathrm{~L}$ ), causing it to take on a highly cellular appearance and making it difficult to distinguish alveolar boundaries.

Similar to alveolar tissue, histological analysis of peripheral and cisternal tissue also determined that

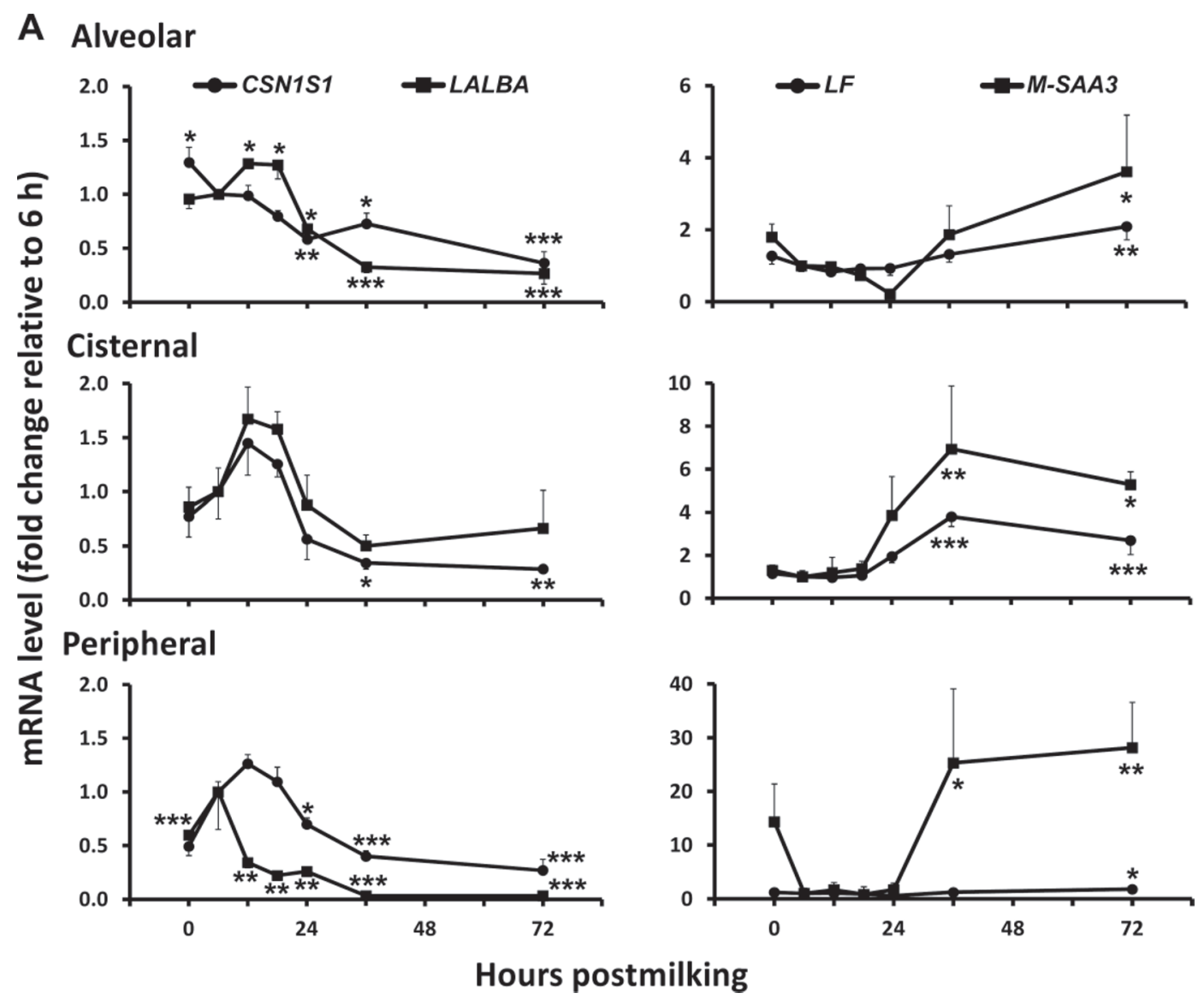

Figure 1. The pattern of gene expression of $L A L B A, C S N 1 S 1$, lactoferrin $(L F)$, and mammary serum amyloid (M-SAA3) during involution of bovine mammary glands induced by termination of milking at mid lactation. (A) Densitometry data are normalized to a $28 \mathrm{~S}$ rRNA band and expressed as mean fold change \pm SEM relative to 6 -h time point for respective genes $\left({ }^{*} P<0.05,{ }^{* *} P<0.01\right.$, $\left.{ }^{* * *} P<0.001\right)$. (B) Northern blot analysis in mammary alveolar, peripheral, and cisternal tissue, following the abrupt cessation of milking. 
B
$\mathbf{O h}$
$6 \mathrm{~h}$
$12 \mathrm{~h}$
$18 \mathrm{~h}$
$24 \mathrm{~h}$
$36 \mathrm{~h}$
$72 \mathrm{~h}$

\begin{tabular}{|c|c|}
\hline \multirow{3}{*}{$\begin{array}{l}\text { Alveolar } \\
\text { 28S RNA }\end{array}$} & LactadoumIII \\
\hline & 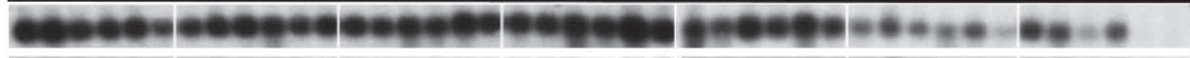 \\
\hline & 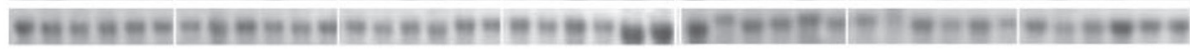 \\
\hline Cisternal & 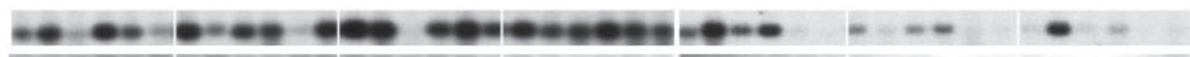 \\
\hline 28S RNA & - \\
\hline p & 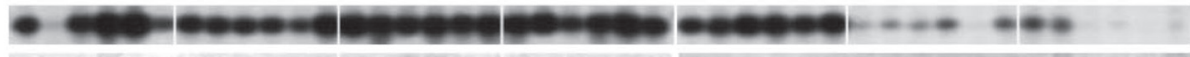 \\
\hline & 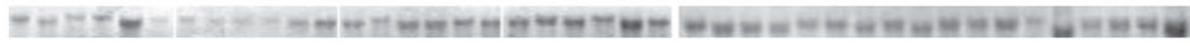 \\
\hline
\end{tabular}

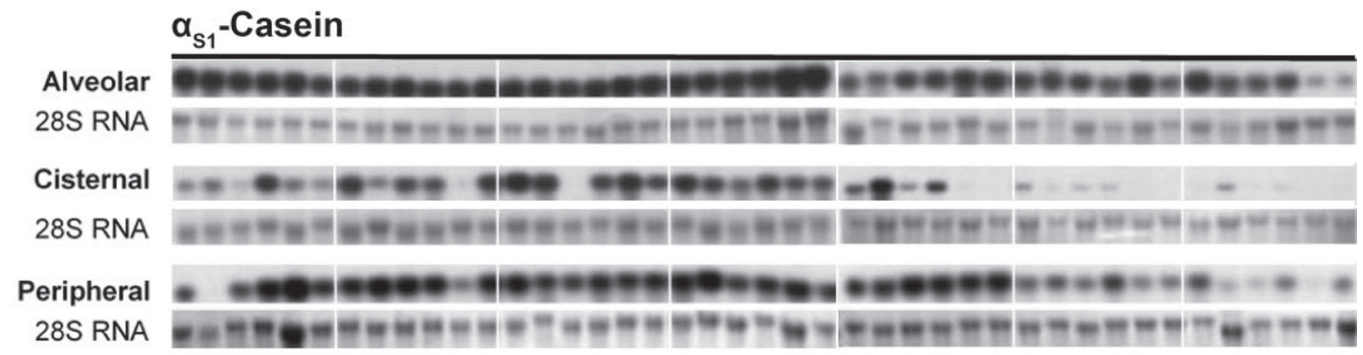

\section{Mammary serum amyloid A3}

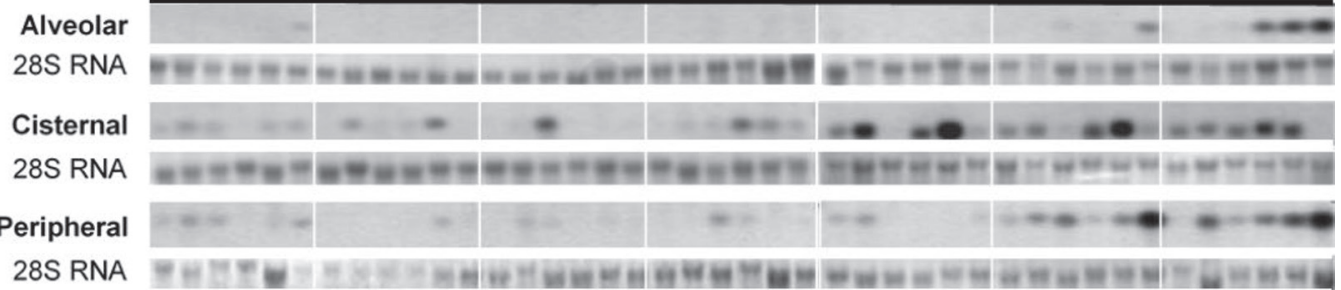

\section{Lactoferrin, overnight exposure}

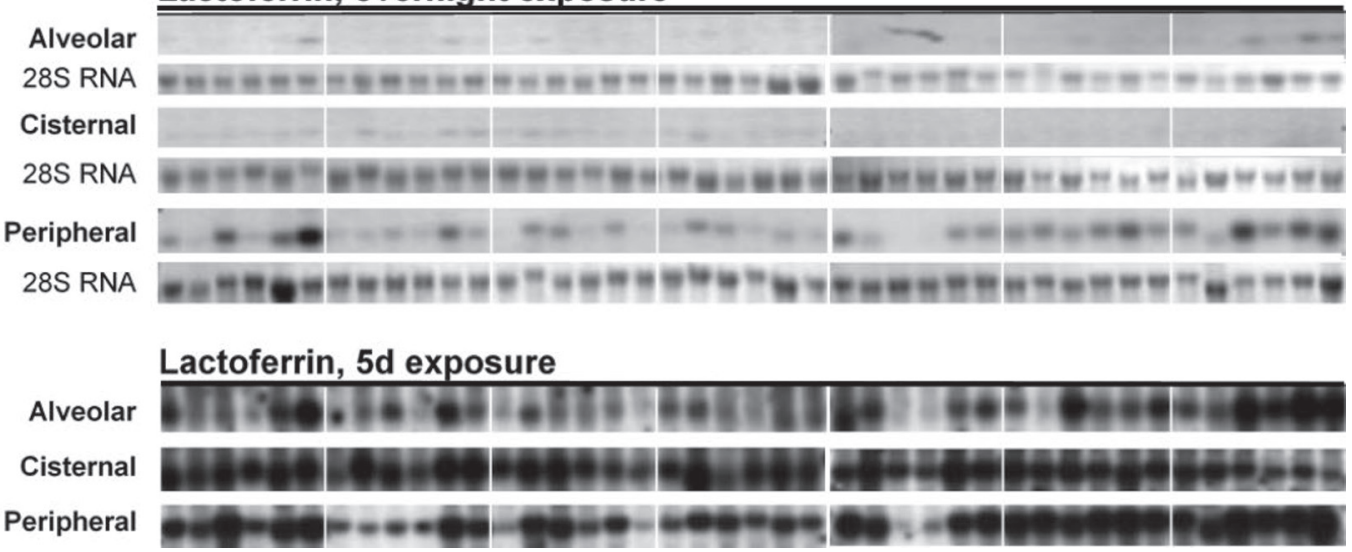

Figure 1 (Continued). The pattern of gene expression of $L A L B A, C S N 1 S 1$, lactoferrin $(L F)$, and mammary serum amyloid (M-SAA3) during involution of bovine mammary glands induced by termination of milking at mid lactation. (A) Densitometry data are normalized to a $28 \mathrm{~S}$ rRNA band and expressed as mean fold change \pm SEM relative to 6 -h time point for respective genes $\left({ }^{*} P<0.05,{ }^{* *} P<0.01,{ }^{* * *} P<0.001\right)$. (B) Northern blot analysis in mammary alveolar, peripheral, and cisternal tissue, following the abrupt cessation of milking.

morphology reflected the level of milk protein mRNA expression (data not shown). The cisternal areas generally consisted of 20 to $70 \%$ connective/fibrous type tissue with embedded lobules of alveoli. In contrast to alveolar tissue, the cisternal compartment throughout all the time points contained a mixture of alveoli that were either open with a lactating phenotype or collapsed with an involuted appearance. The peripheral 


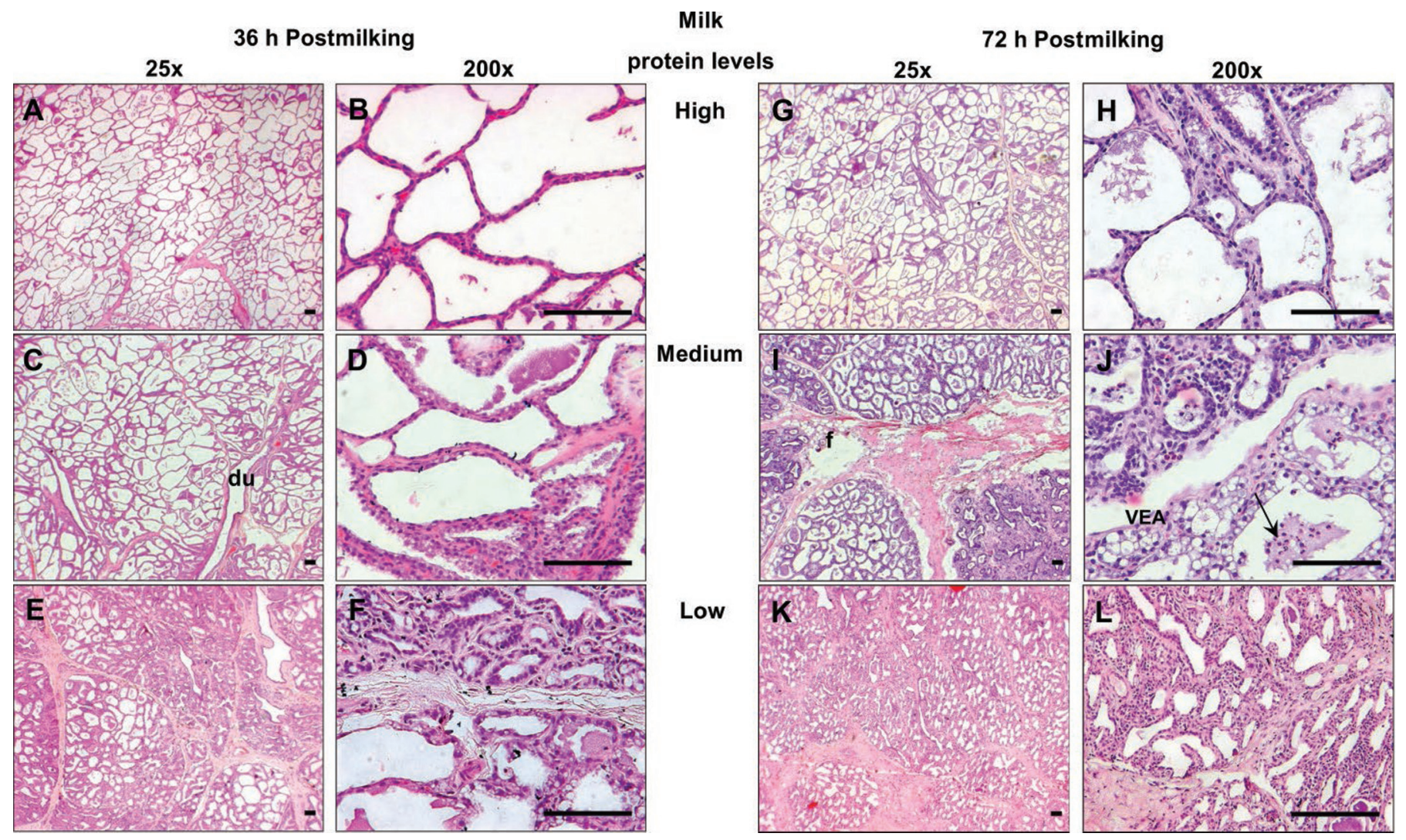

Figure 2. Morphology of bovine alveolar mammary tissue during involution following the abrupt cessation of milking in mid lactation. Representative hematoxylin-and-eosin-stained sections are shown at $25 \times$ and $200 \times$ magnification for glands at $36 \mathrm{~h}(\mathrm{~A}-\mathrm{F})$ and $72 \mathrm{~h}(\mathrm{G}-\mathrm{L})$ postmilking. Histological variation was observed between animals with high (A, B, G, H), moderate (C, D, I, J), and low (E, F, K, L) relative $\alpha$-LA mRNA expression at the later time points. Examples of ducts (du), fat cells (f), vesicle-engorged alveoli (VEA), and leukocytes (arrows) are shown. Scale bars are at $100 \mu \mathrm{m}$. Color version available online.

tissue, which is arranged in bands surrounding the entire udder quarter, was typified by a lower proportion of fibrous connective tissue than the cisternal tissue. The alveolar lobules in this compartment tended to be larger than cisternal tissue and the alveoli had a more lactation-like appearance up to and including the $24 \mathrm{~h}$ time point. From $36 \mathrm{~h}$ postmilking, the proportion of distended and involuting alveoli increased.

\section{Heterogeneity in Apoptosis of MEC During Involution}

By $36 \mathrm{~h}$ postmilking, variation was observed in the extent of apoptosis between cows, which was associated with the morphology of the alveolar tissue section and the milk protein mRNA levels (Figure 3). Animals that were at a more advanced stage of involution within the 36- and 72-h time points, with lower relative milk protein (and higher relative immune-related gene) mRNA expression, had increased numbers of apoptotic nuclei (Figures $3 \mathrm{C}$ and $3 \mathrm{~F}$ ).
Across the time course of mammary involution, the mRNA expression levels of $L A L B A$ and CSN1S1 were negatively associated with $\log (1+$ number of ISEL nuclei per alveolus; $\mathrm{r}=-0.64, P<0.001 ; \mathrm{r}=-0.71, P$ $<0.001$, respectively, Figure 4). The $M-S A A 3$ and $L F$ mRNA expression were positively correlated with $\log$ $(1+$ number of ISEL nuclei per alveolus; $\mathrm{r}=0.76, P<$ $0.001 ; \mathrm{r}=0.46, P<0.05$, respectively, Figure 4).

\section{Heterogeneity in STAT5-P and STAT3-P Protein Abundance in Mammary Gland During Involution}

Representative Western blots for the time series of STAT5-P and STAT3-P are presented in Figure 5. The later time points, 36 and $72 \mathrm{~h}$ postmilking, indicate reciprocal expression of STAT5-P and STAT3-P. Within these time points, the samples identified with high milk protein levels $(\mathrm{H})$ had intense signal for STAT5-P and low or barely detectable levels for STAT3-P. Similar to mammary tissue with high milk protein levels, the 
High

\section{$36 \mathrm{~h}$ Postmilking}

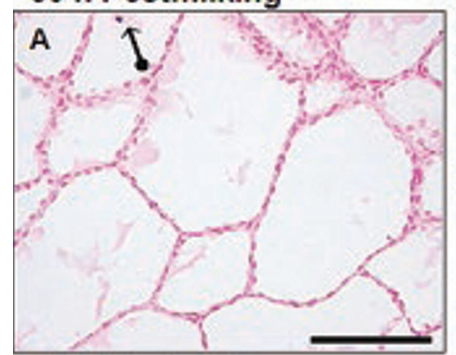

$72 \mathrm{~h}$ Postmilking

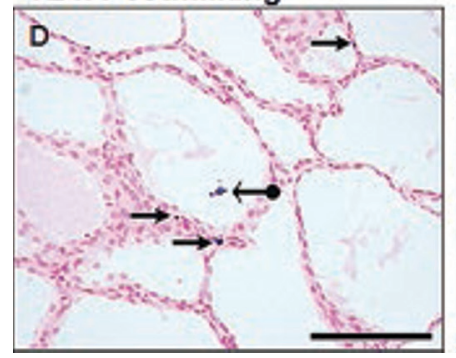

Medium
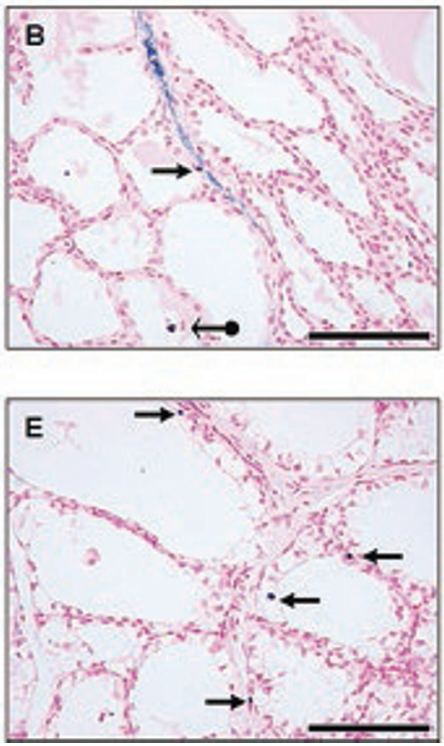

Low
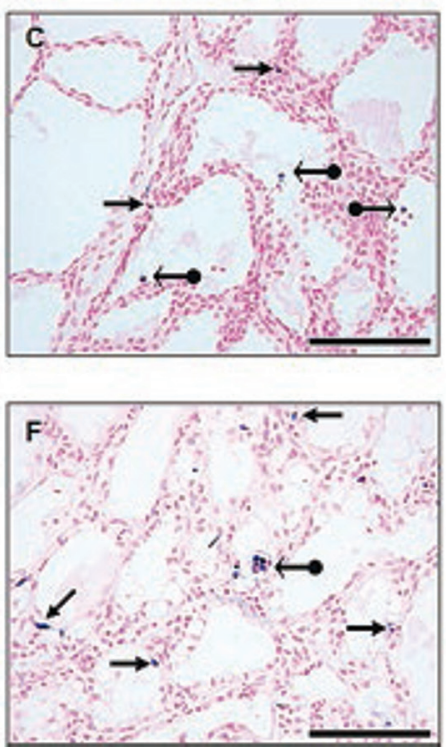

\section{Negative control}

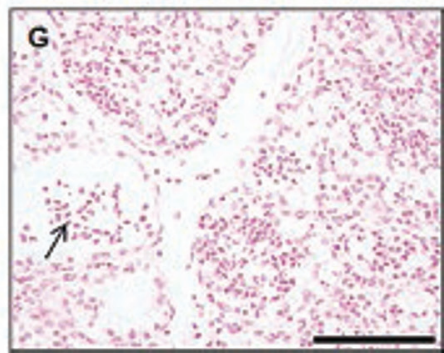

Figure 3. In situ end-labeling (ISEL) of apoptotic nuclei in bovine alveolar mammary issue following the abrupt cessation of milking in mid lactation. Representative images from mammary alveolar with high (A, D), moderate (B, E), and low (C, F) relative milk protein mRNA expression at $36 \mathrm{~h}(\mathrm{~A}-\mathrm{C})$ and $72 \mathrm{~h}(\mathrm{D}-\mathrm{F})$ postmilking, and negative control $(\mathrm{G})$, are shown at $200 \times$ magnification. Positive ISEL nuclei, which indicate apoptosis, are darker than the other nuclei and in the online version are labelled blue-black. Sections were counterstained with nuclear fast red. Examples of epithelial ISEL nuclei (bold arrow), luminal ISEL nuclei (single or regions; arrow with solid circle on end), and regions of leukocyte invasion (regular arrow) are shown. Scale bar is at $100 \mu \mathrm{m}$. Color version available online.

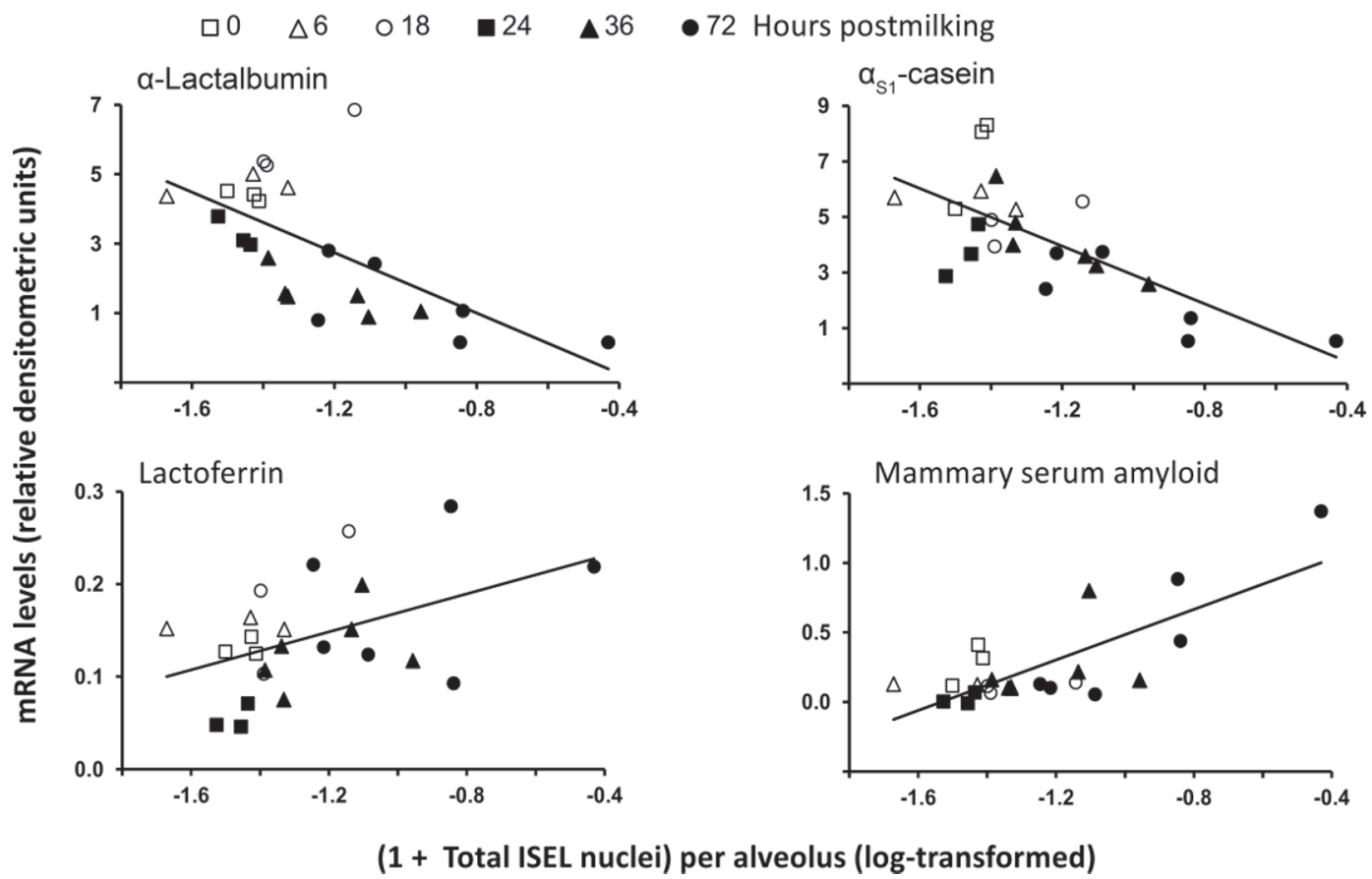

Figure 4. The relationship between in situ end-labeling (ISEL) of apoptotic nuclei and expression of LALBA, CSN1S1, mammary serum amyloid ( $M-S A A 3)$, and lactoferrin $(L F)$ mRNA, during involution of bovine mammary glands. 

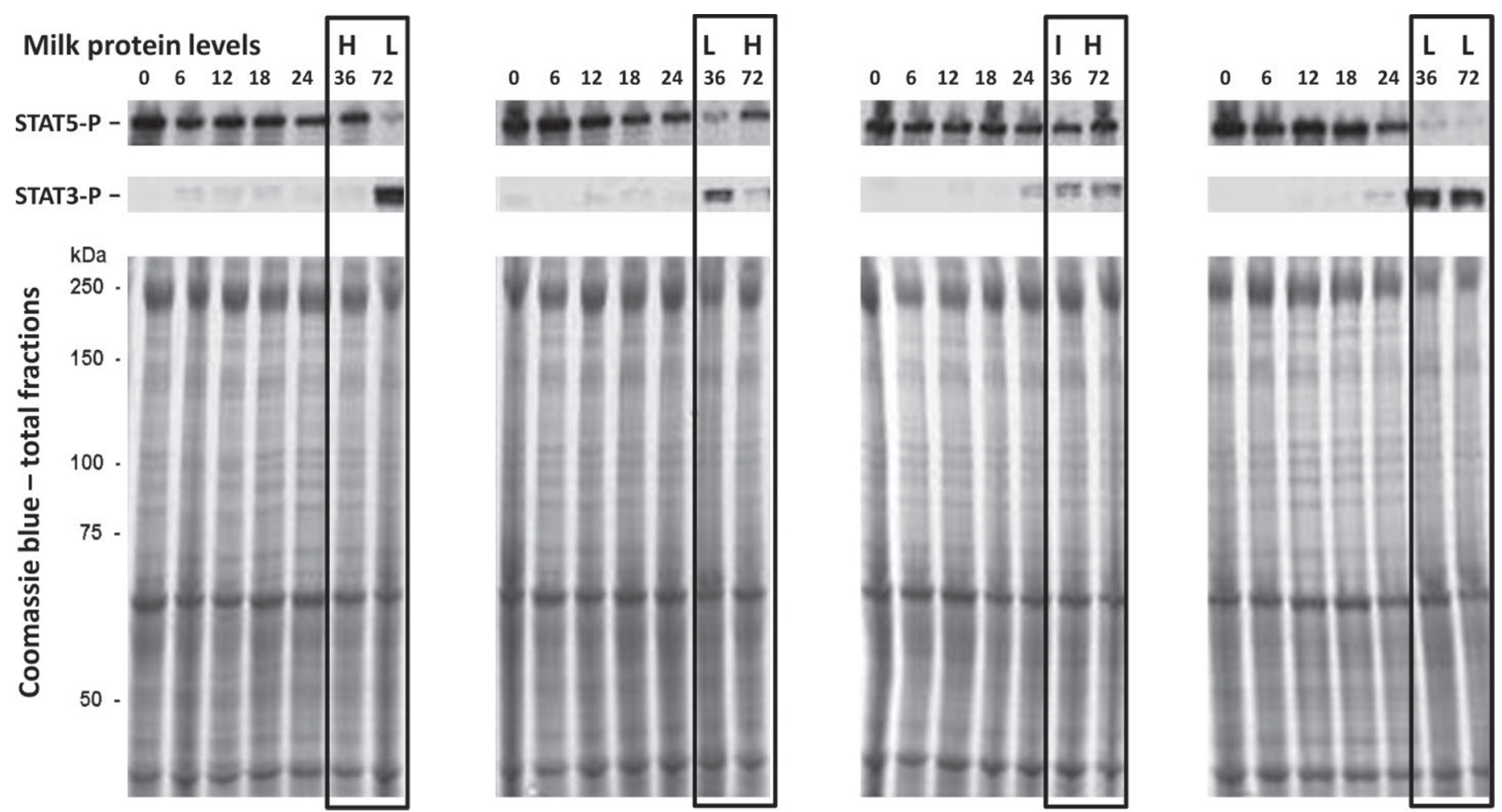

Figure 5. Qualitative Western blot analysis of signal transducer and activator of transcription (STAT) phosphorylated (P) 5-P and STAT3-P protein in mammary alveolar tissue following the abrupt cessation of milking in mid lactation. Samples identified as having high (H), intermediate (I), and low (L) milk protein levels are indicated at 36 and $72 \mathrm{~h}$ postmilking. Duplicate gels were stained with Coomassie blue to indicate uniformity of loading per lane for the total homogenate (STAT5, STAT5-P, and STAT3) and soluble fractions (STAT3-P, data not shown). Molecular masses are indicated to the left of the panels.

samples with moderate or intermediate milk protein levels also had an intense signal for STAT5-P, but in contrast, the signal for STAT3-P was more intense. However, those identified with low milk protein levels had low or barely detectable signal for STAT5-P and intense signal for STAT3-P.

Immunohistochemistry analysis showed that by $72 \mathrm{~h}$ postmilking (Figure 6), the degree of signal for STAT5$\mathrm{P}$ was related to the degree of involution in each animal. That is, in the samples that had high $L A L B A$ expression most of the nuclei were still intensely labeled for STAT5-P (Figure 6A) and STAT3-P (Figure 6B). In the samples with low levels of $L A L B A$ expression, the STAT5-P was still detected but with varying levels of intensity and not in all the nuclei, and it was also evident in the lumen of VEA (Figure 6C). In contrast, the STAT3-P was intensely labeled in the majority of nuclei (Figure 6D). It was not possible to detect the proportion of labeled nuclei between areas of different morphological appearance within sections that had tissue heterogeneity. Furthermore, within the later time points, in samples with high levels of $L A L B A$ expression there was more background staining of accumu- lated milk remaining in the alveolar lumen for STAT5$\mathrm{P}$ (Figure 6A) and STAT3-P (Figure 6B) sections, compared with low $L A L B A$ expression where there was very little staining of accumulated milk (Figures 6C and 6D). Negative controls for tissues both STAT5-P and STAT3-P had no detectable signal in MEC nuclei (Figure 6).

\section{Heterogeneity in Milk Protein and Immune-Related Gene Expression in Mammary Gland}

The within-udder comparisons of the $L A L B A$, $C S N 1 S 1$, and $L F$ mRNA expression in alveolar tissue from multiple sites within quarters of lactating cows are presented in Figure 7. More variability in expression of both $L A L B A$ and $C S N 1 S 1$ was observed between cows and between quarters within a cow than within quarters (Table 1). The $L F$ mRNA levels were barely detectable in the lactating tissue (Figure 7), although even at this low level of expression variation was greater between cows and between quarters within a cow than within quarters (Table 1). An over-exposed Northern analysis indicated the high degree of variability in $L F$ mRNA 

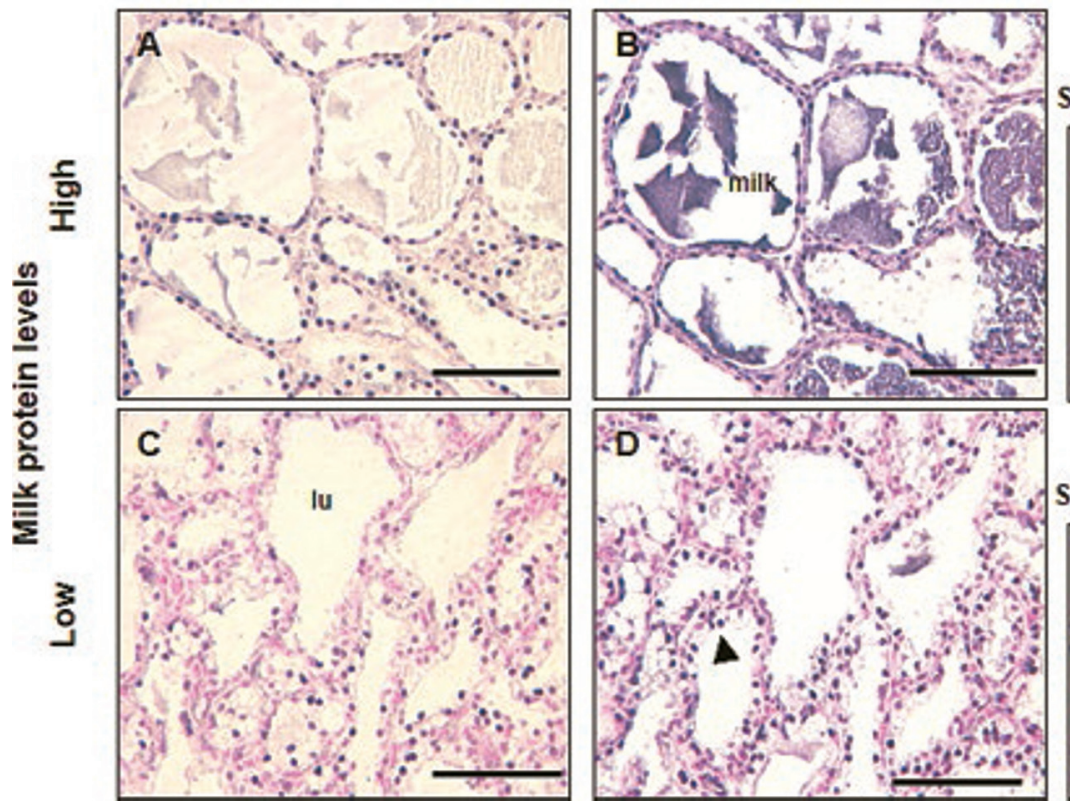

STAT5-P negative control

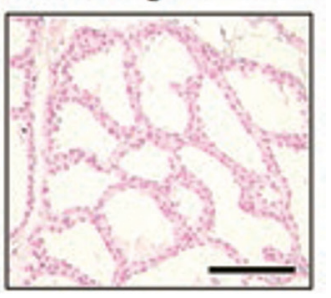

STAT3.P negative control

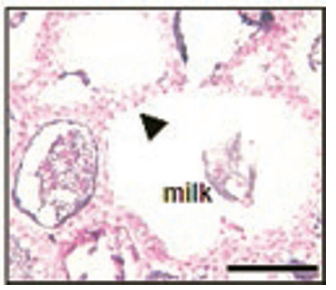

Figure 6. Localization of signal transducer and activator of transcription (STAT) phosphorylated (P) 5-P and STAT3-P in bovine alveolar mammary tissue $72 \mathrm{~h}$ postmilking. Representative sections of samples from tissue with high (A, B) or low (C, D) milk protein levels are shown at $200 \times$ magnification. Sections were counterstained either in eosin (A, B) or nuclear fast red (C, D), and positive nuclei appear darker than unlabelled nuclei. Examples of lumen (lu), milk staining (milk), and nuclei (arrowheads) are shown. Scale bars are at $100 \mu \mathrm{m}$. Color version available online.

expression (Figure 7). The M-SAA3 mRNA levels were not detectable in the alveolar tissue of lactating quarters (data not shown).

\section{Spatial Heterogeneity in Milk Protein and Immune- Related Gene Expression in Mammary Gland During Lactation}

In situ hybridization of CSN1S1 indicated that most alveoli at $6 \mathrm{~h}$ postmilking were positively labeled (Figure 8). However, heterogeneity was present in CSN1S1 expression between adjacent alveoli lobules containing alveoli with either a lactating phenotype and intense CSN1S1 signal, involuting phenotype and no signal, or a combination (Figure 8A). Interestingly, the sample depicted in Figure 8A had an area of tissue that had more heterogeneity between neighboring alveoli lobules than other 6-h samples. This sample had a region of collapsed alveoli, and thus an involuted appearance, with no expression of CSN1S1 in this region. Within lobules, heterogeneity was also present in CSN1S1 expression within areas of open alveoli that appeared to have a lactating morphology (Figure 8B). The variation in label intensity observed within these alveolar lobules appeared to be related to visible milk accumulation in the lumen, indicative of early stasis. The alveoli that did not have visible milk accumulation in the lumen had intense labeling for CSN1S1, whereas those with milk accumulation had a less intense signal. A gradient of intensity for CSN1S1 labeling was also observed within some alveoli (Figure 8C). In Figure 8D, an abrupt transition of CSN1S1 at small/large duct junction (up arrow) and cessation of CSN1S1 in large duct epithelial cells (dotted arrow) is depicted. The negative control had no detectable CSN1S1 label (Figure 8E).

\section{Spatial Heterogeneity in Milk Protein and Immune- Related Gene Expression in the Mammary Gland During Involution}

At $192 \mathrm{~h}$ postmilking, in situ hybridization of CSN1S1 indicated that most alveoli were positively labeled in mammary gland from a cow identified with high milk protein levels (Figure 9A). However, there were also regions of alveoli with no CSN1S1 signal (Figures 9A and 9B). Furthermore, there was very little or barely detectable positive labeling for LF (Figure 9C). In contrast, in mammary gland from a cow identified with low milk protein levels, there were only small regions of alveoli positively labeled for CSN1S1 (Figures 9D to 9F) and more alveoli were positively labeled for $L F$ (Figures 9G to 9I). In Figures 9F and 9I, a region of alveoli with 
Table 1. Variability in expression of $L A L B A, C S N 1 S 1$, and lactoferrin $(L F)$ in mammary alveolar tissue of lactating cows ${ }^{1}$

${ }^{1}$ Mammary alveolar tissue was collected from 5 different sites in each udder quarter of 3 lactating cows $6 \mathrm{~h}$ postmilking. Northern blot analysis of $L A L B A, C S N 1 S 1, L F$, and mammary serum amyloid (M-SAA3) was carried out. No expression of $M$-SAA3 was detected $6 \mathrm{~h}$ postmilking. The variation in gene expression by cows, quarters within cows, and sites within quarter was estimated from a variance component analysis on the $\log _{10}$ normalized densitometry values. The 3 variance components are presented as a percentage of the total variance.

\begin{tabular}{lccc}
\hline Variation (\%) & CSN1S1 & LALBA & LF \\
\hline Between cows & 24 & 49 & 35 \\
Between quarters within cows & 67 & 28 & 52 \\
Within quarters & 9 & 24 & 13 \\
\hline
\end{tabular}

positive labeling for both $C S N 1 S 1$ and $L F$, respectively, can be detected. However, within these alveoli, some MEC that were intensely labeled positive for $C S N 1 S 1$ (Figure 9F) were negative for $L F$ (Figure 9I), and some MEC that were negative for CSN1S1 (Figure 9F) were intensely labeled positive for $L F$ (Figure 9I). The negative control had no detectable $L F$ label (Figure 9).

\section{DISCUSSION}

The present study demonstrated heterogeneity in tissue morphology and gene expression (milk protein and

B
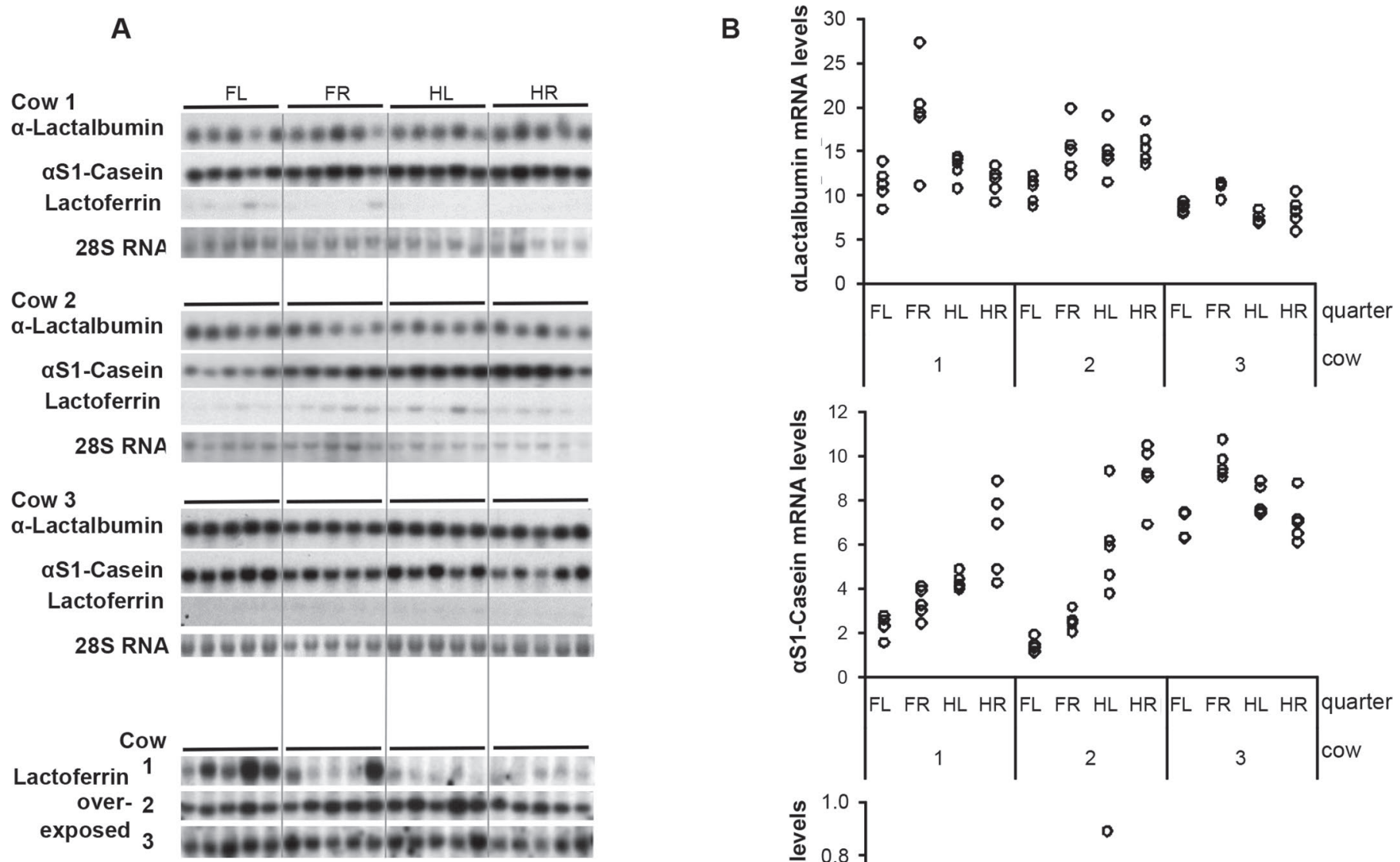

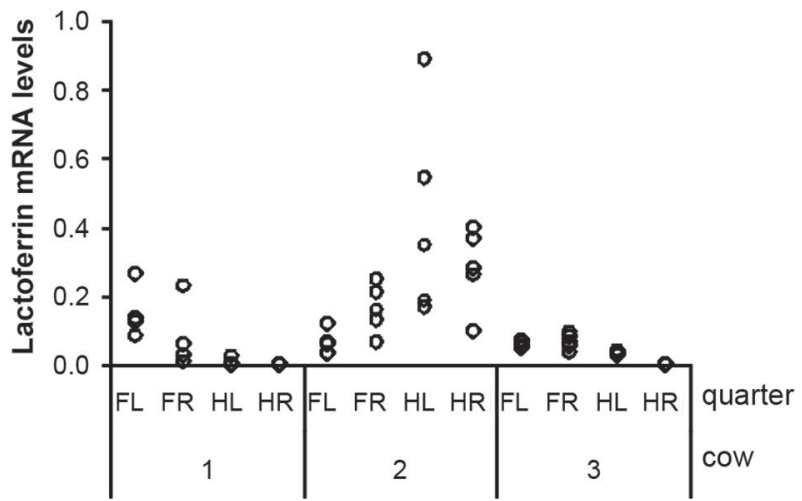

Figure 7. (A) Northern blot analysis of $\alpha-\mathrm{LA}, \alpha_{\mathrm{S1} 1} \mathrm{CN}$, and lactoferrin from alveolar tissue collected from 5 different alveolar tissue sites in each udder quarter of lactating cows $6 \mathrm{~h}$ postmilking $(\mathrm{n}=3)$. (B) Densitometry data are normalized to the $28 \mathrm{~S}$ rRNA band. The data are expressed as $\log _{10}$ normalized densitometry values. $\mathrm{FL}=$ front left; $\mathrm{FR}=$ front right; $\mathrm{HL}=$ hind left; $\mathrm{HR}=$ hind right. 
immune-related genes) in mammary glands of pasturefed dairy cows. In alveolar tissue at mid-lactation $(6 \mathrm{~h}$ postmilking), there was a small degree of variability in milk protein gene expression within mammary gland quarters. Although the majority of alveoli were open and expressing milk protein genes, some lobules and alveoli with an open lactating morphology were quiescent (i.e., not producing milk proteins). This result is similar to earlier findings in beef cows and sheep indicating that populations of both active and quiescent alveoli exist within lactating mammary tissue (Molenaar et al., 1992, 1996a; Farr et al., 1996). In the present study, heterogeneity in milk protein gene expression was also detected within alveoli, indicating secretory MEC of an alveolus differ in functional persistency and enter involution at different times. In contrast to beef cows and sheep (Molenaar et al., 1992, 1996a; Farr et al., 1996), during lactation of the dairy cow, fewer regions of alveoli had a collapsed, involuting morphology, which is consistent with their greater milk production outputs. Heterogeneity of milk protein and immune-related gene expression during lactation was not evident in an earlier report examining the bovine mammary gland (Wilde et al., 1997). This difference may be due to several factors including either breed differences, stage of lactation, or nutrition. The cows in the present study were fed solely pasture, whereas in the earlier report (Wilde et al., 1997) the cows were fed a concentrate-forage diet, indicating nutrition may regulate the proportion of active and quiescent cells (Vetharaniam et al., 2003b).

During involution, in comparison to lactating tissue, there were more alveoli with VEA and a collapsed involuting appearance, which was associated with a greater heterogeneity of milk protein and $L F$ abundance be-

\section{CSN1S1 heterogeneity during lactation}

Between alveolar lobules

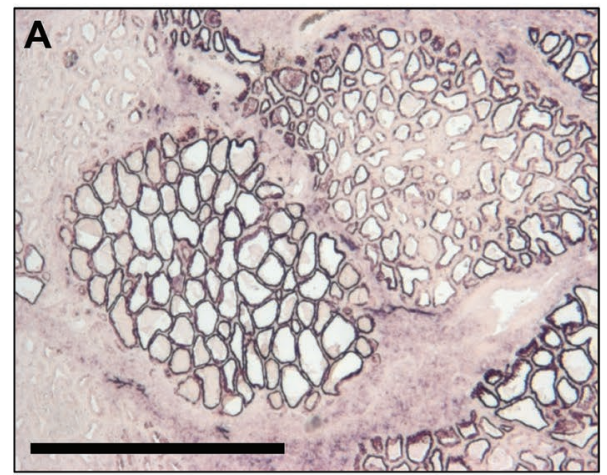

Between alveoli within lobules

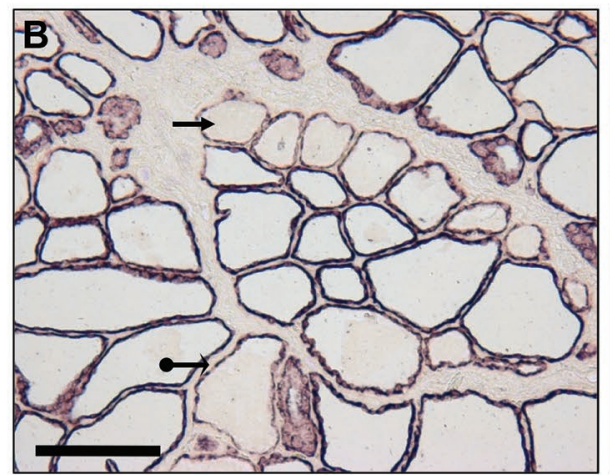

Within alveolus

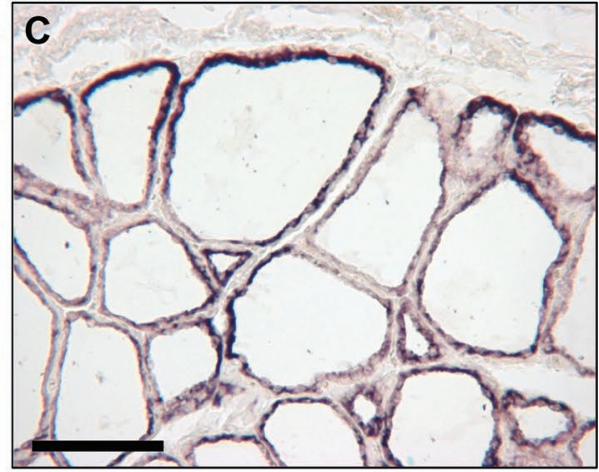

Within ducts

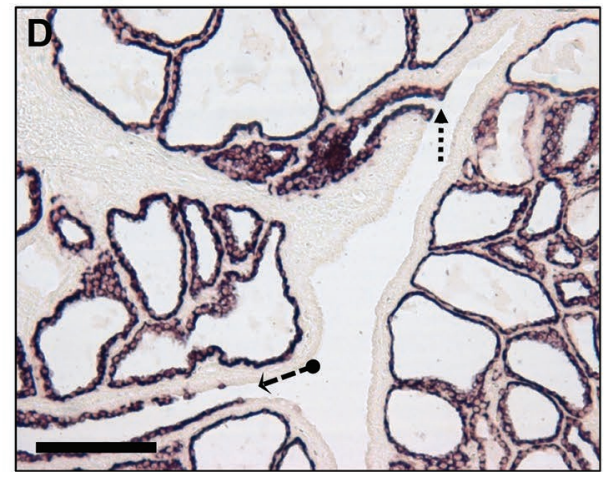

Negative control

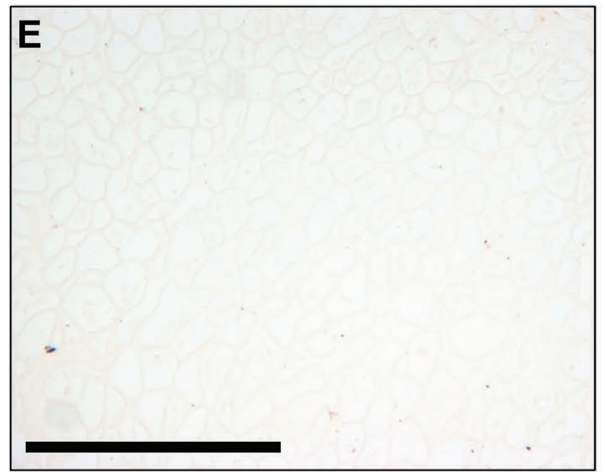

Figure 8. In situ hybridization analysis of CSN1S1 in mammary alveolar tissue of the lactating cow. Representative images demonstrating heterogeneity (A) between adjacent alveolar lobules containing alveoli with either lactating phenotype and intense $C S N 1 S 1$ signal, involuting phenotype and no signal, or a combination; (B) within alveoli lobules, with visible accumulated luminal milk content and low signal intensity, and alveoli without luminal content with intense signal; (C) within alveolus; and (D) within ducts. Examples of alveoli with visible accumulated luminal milk and low (solid arrow) or gradient (arrow with solid circle on end) intensity of positive CSN1S1 signal within the alveolus are shown. Examples of an abrupt transition of gene expression at small/large duct junction (dashed arrow) and cessation of casein expression in large duct epithelial cells (dashed arrow with solid circle on end) are also shown. (E) Shows a negative control for CSN1S1. Scale bars are at (A, E) 1,000 $\mu \mathrm{m}$, (B, D) $150 \mu \mathrm{m}$, and (C) $100 \mu \mathrm{m}$. Color version available online. 
tween alveoli. The VEA (also called vacuole-containing alveoli) are defined as alveoli in which large vacuoles containing fat droplets and material from secretory vesicles are present within MEC and high numbers of vesicles containing coalescing fat droplets and proteins exist in the alveolar lumen (Holst et al., 1987; Hurley, 1989; Oliver and Sordillo, 1989). This observation also confirms earlier findings that investigated the onset of involution in beef cows, sheep (Molenaar et al., 1992, 1996a), and dairy cows (Wilde et al., 1997). These morphological changes (Holst et al., 1987; Sordillo and Nickerson, 1988; Hurley, 1989) and reciprocal expression of milk protein and immune-related genes during bovine mammary gland involution have previously been reported (Goodman and Schanbacher, 1991). However, the present study demonstrated that these changes were variable between cows from $36 \mathrm{~h}$ postmilking and were associated with the degree of MEC apoptosis in the alveolar tissue. The time course of apoptosis of MEC in alveolar tissue was presented previously, with little apoptosis detected between 0 to $24 \mathrm{~h}$ postmilking and an increase in the number of apoptotic ISEL nuclei detected by $72 \mathrm{~h}$ postmilking (Singh et al., 2005). The present study demonstrates that within the 36 and $72 \mathrm{~h}$ postmilking time points, cows with the greatest reduction in milk protein gene expression had more alveoli with an involuting morphology and more apoptotic products, compared with cows with a lower reduction in milk protein gene expression.

During bovine involution, the decline in milk protein gene expression is associated with the decline in STAT5P (Singh et al., 2016). In the present study, whereas STAT5-P protein abundance was downregulated during the bovine mammary involution process, STAT3-P was upregulated. The interaction of STAT5 and STAT3 at the onset of involution is unclear; however, studies indicate that, in addition to a role in lactogenesis (Liu et al., 1997), the activation of STAT5 is a survival signal in MEC that suppresses STAT3-mediated apoptosis (Clarkson et al., 2006). Furthermore, leukemia

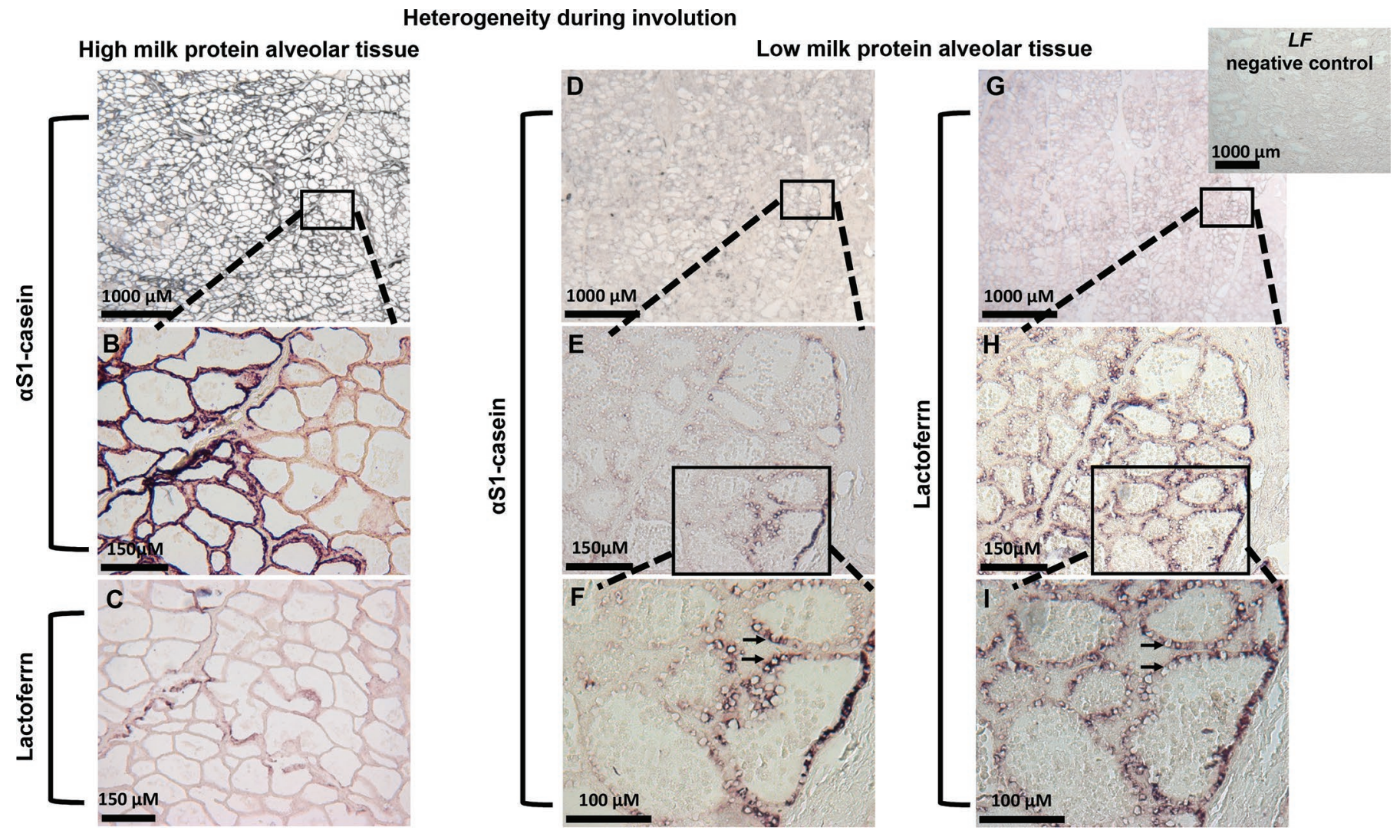

Figure 9. Representative images of in situ hybridization analysis of CSN1S1 and lactoferrin $(L F)$ in 8-d-postmilking involuting mammary alveolar tissue identified by Northern analysis as having high or low milk protein levels. High milk protein sample labeled with (A, B) CSN1S1 and (C) $L F$. Low milk protein sample labeled with (D-F) CSN1S1 and (G-I) $L F$. A representative negative control for a $L F$, low milk protein sample is shown. A representative negative control for CSN1S1 is shown in Figure 8. Scale bars are (A, D, G) 1,000 $\mu \mathrm{m},(\mathrm{B}, \mathrm{C}, \mathrm{E}, \mathrm{H}) 150 \mu \mathrm{m}$, and (F, I) $100 \mu \mathrm{m}$. Dashed lines indicate areas of enlargement. Examples of regions demonstrating reciprocal labeling of CSN1S1 and LF (arrow). Color version available online. 
inhibitory factor-signal transducer, which activates STAT3 (Chapman et al., 1999; Kritikou et al., 2003), negatively modulates STAT5 activation (Granillo et al., 2007) and can inhibit PRL induction of milk protein gene expression and STAT5 activation (Dif et al., 2001). The present study demonstrates that within the same time point during early involution (36 and $72 \mathrm{~h}$ postmilking), the reciprocal expression of STAT5-P and STAT3-P protein was related to the proportion of lactating and nonlactating phenotype and to the extent of apoptosis of MEC. Thus, individual cows vary in their loss of MEC secretory function, rate of cell survival and cell death signals, and rate of MEC apoptosis during involution following the abrupt cessation of milk removal.

In bovines, milk production was fully recovered after resuming milking following a 7 -d nonmilking period (Farr et al., 1998; Dalley and Davis, 2006; Singh et al., 2015), and partially restored following 14 and $28 \mathrm{~d}$ nonmilking (Singh et al., 2015). These results indicate that the increase in cell loss observed during early involution in the present study is not sufficient to shut down lactation completely in the dairy cow and the regressing alveoli detected at mid-lactation are in the early phases of involution and not yet committed to cell death. The cells in these regressing alveoli may be quiescent and have not progressed to the senescent state. Quiescent alveoli may be capable of reactivation to their active state (Davis et al., 1999; Shorten et al., 2002; Vetharaniam et al., 2003a). This supports earlier reports that demonstrate remodeling of the mammary gland during involution in ruminants occurs to a lesser extent than in rodents (Wilde et al., 1999; Capuco and Akers, 1999), only replacing senescent or damaged cells (Capuco et al., 2001). The retention of alveoli that are actively expressing milk proteins and the quiescent state of regressing alveoli may play a role in the reversibility following extended nonmilking intervals in bovine mammary function.

The variation in expression of milk protein and immune-related genes between individual sampling sites within and across mammary gland quarters indicates that sampling site effects should be considered when measuring gene expression changes in the bovine mammary gland. Peripheral tissue appears morphologically distinct from lactating tissue and somewhat in between lactating and involuted tissues, in that it contains a proportion of both tissue types. Cisternal tissue appears more duct-like and can easily be mistaken for involuted tissue. Hence, investigators collecting mammary samples by biopsy need to take care of what tissue is taken, as the mammary tissue that is visible by dissection under the skin $(1-2 \mathrm{~cm})$ does not reflect the tissue in deeper parts of the gland. In this study, the expression of milk protein and immune-related genes in those peripheral and cisternal tissue were quite variable as shown in the Northern analysis, with these tissues being able to express both lactation and defense protein genes in varying proportion.

Although it is clear that local intramammary signals initiate involution and apoptosis of MEC ( $\mathrm{Li}$ et al., 1997), the actual trigger is still unknown. Possibilities include the accumulation of casein fractions (Shamay et al., 2003) or serotonin (Matsuda et al., 2004; Collier et al., 2012) in milk, or physical distension of the mammary gland, which results in changes in cell shape that may activate mechanotransduction pathways (Davis et al., 1999; Stelwagen, 2001). In support, cell-cell communication (Cooper et al., 2004), cell-extracellular matrix communication (Singh et al., 2005), and the primary cilia of mechanosensors (Millier et al., 2013; Biet et al., 2016) were disrupted following milk engorgement at the onset of involution of the bovine mammary gland. Furthermore, acute physical distension of rat mammary glands with sucrose solution in vivo accelerated the onset of apoptosis of MEC, disruption of cell-cell and cell-extracellular matrix communication, and activation of STAT3 (Phyn et al., 2007). In bovine, this treatment suppressed milk secretion (Stelwagen et al., 1998) and milk protein gene expression (Biet et al., 2013). Understanding the mechanisms initiating the process of involution of individual alveoli within lactating and involuting gland will allow the enhancement of milk production.

\section{CONCLUSIONS}

Examination of mammary tissue morphology, gene expression (milk protein and immune-related genes), transcription factors involved in cell survival and cell death signaling (STAT5 and STAT3), and MEC apoptosis demonstrated heterogeneity of the involution process. This occurs at multiple levels including between quarters within a cow, within mammary glands (between and within alveolar lobules and between different regions of the gland), as well as between cows. This indicates alveoli enter involution asynchronously, and a large variation is present in the rate of involution of the mammary gland between cows. Understanding the mechanisms initiating these changes in lactating and involuting mammary provides an opportunity for enhancing milk production of the dairy cow.

\section{ACKNOWLEDGMENTS}

Financial support from the Ministry of Business, Innovation and Employment, Wellington, New Zealand is gratefully acknowledged. 


\section{REFERENCES}

Biet, J., C. A. Poole, K. Stelwagen, J. K. Margerison, and K. Singh. 2016. Primary cilia distribution and morphology during involution of the bovine mammary gland. J. Dairy Sci. 99:3966-3978.

Biet, J., K. Stelwagen, J.K. Margerison, C.A. Poole, A. Cullum, and K. Singh. 2013. Changes in the mechanical microenvironment of the bovine mammary gland and their effect on mammary function. J. Dairy Sci. 96(E-Suppl. 1):570.

Capuco, A. V., and R. M. Akers. 1999. Mammary involution in dairy animals. J. Mammary Gland Biol. Neoplasia 4:137-144.

Capuco, A. V., D. L. Wood, R. Baldwin, K. McLeod, and M. J. Paape. 2001. Mammary cell number, proliferation, and apoptosis during a bovine lactation: Relation to milk production and effect of bST. J. Dairy Sci. 84:2177-2187.

Chapman, R. S., P. C. Lourenco, E. Tonner, D. J. Flint, S. Selbert, K. Takeda, S. Akira, A. R. Clarke, and C. J. Watson. 1999. Suppression of epithelial apoptosis and delayed mammary gland involution in mice with a conditional knockout of Stat3. Genes Dev. $13: 2604-2616$

Church, G. M., and W. Gilbert. 1984. Genomic sequencing. Proc. Natl. Acad. Sci. USA 81:1991-1995.

Clarkson, R. W., M. P. Boland, E. A. Kritikou, J. M. Lee, T. C. Freeman, P. G. Tiffen, and C. J. Watson. 2006. The genes induced by signal transducer and activators of transcription STAT3 and STAT5 in mammary epithelial cells define the roles of these STATs in mammary development. Mol. Endocrinol. 20:675-685.

Clarkson, R. W., M. T. Wayland, J. Lee, T. Freeman, and C. J. Watson. 2004. Gene expression profiling of mammary gland development reveals putative roles for death receptors and immune mediators in post-lactational regression. Breast Cancer Res. 6:R92R109.

Collier, R. J., L. L. Hernandez, and N. D. Horseman. 2012. Serotonin as a homeostatic regulator of lactation. Domest. Anim. Endocrinol. 43:161-170.

Cooper, C., K. Stelwagen, K. Singh, V. C. Farr, C. G. Prosser, and S. R. Davis. 2004. Expression of the tight junction protein zonula occludens-1 during mammary engorgement. Proc. N.Z. Soc. Anim. Prod. 64:43-47.

Dalley, D. E., and S. R. Davis. 2006. Effect of an extended milking interval on recovery of milk yield and somatic cell count in dairy cows. Proc. N.Z. Soc. Anim. Prod. 66:241-244.

Davis, S. R., V. C. Farr, and K. Stelwagen. 1999. Regulation of yield loss and milk composition during once-daily milking: A review. Livest. Prod. Sci. 59:77-94.

Dif, F., E. Saunier, B. Demeneix, P. A. Kelly, and M. Edery. 2001 Cytokine-inducible SH2-containing protein suppresses PRL signaling by binding the PRL receptor. Endocrinology 142:5286-5293.

Farr, V. C., K. Stelwagen, L. R. Cate, A. J. Molenaar, T. B. McFadden, and S. R. Davis. 1996. An improved method for the routine biopsy of bovine mammary tissue. J. Dairy Sci. 79:543-549.

Farr, V. C., K. Stelwagen, and S. R. Davis. 1998. Rates of recovery of milk yield and composition following milking intervals of varying length. Proc. N.Z. Soc. Anim. Prod. 58:47-48.

GenStat. 2011. VSN International. GenStat for Windows 14th ed. GenStat.co.uk. Hemel Hempstead, UK.

Goodman, R. E., and F. L. Schanbacher. 1991. Bovine lactoferrin mRNA: Sequence, analysis, and expression in the mammary gland. Biochem. Biophys. Res. Commun. 180:75-84.

Granillo, A. R., J. C. Boffi, L. Barañao, E. Kordon, A. Pecci, and A. Guberman. 2007. STAT5 transcriptional activity is impaired by LIF in a mammary epithelial cell line. Biochem. Biophys. Res. Commun. 356:727-732

Herrin, D. L., and G. W. Schmidt. 1988. Rapid, reversible staining of northern blots prior to hybridization. Biotechniques 6:196-197. 199-200

Holst, B. D., W. L. Hurley, and D. R. Nelson. 1987. Involution of the bovine mammary gland: Histological and ultrastructural changes. J. Dairy Sci. 70:935-944.

Hurley, W. L. 1989. Mammary gland function during involution. J. Dairy Sci. 72:1637-1646.
Hurley, W. L., and L. A. Schuler. 1987. Molecular cloning and nucleotide sequence of a bovine alpha-lactalbumin cDNA. Gene 61:119 122.

Kritikou, E. A., A. Sharkey, K. Abell, P. J. Came, E. Anderson, R. W. Clarkson, and C. J. Watson. 2003. A dual, non-redundant, role for LIF as a regulator of development and STAT3-mediated cell death in mammary gland. Development 130:3459-3468.

Li, M., X. Liu, G. Robinson, U. Bar-Peled, K. U. Wagner, W. S. Young, L. Hennighausen, and P. A. Furth. 1997. Mammary-derived signals activate programmed cell death during the first stage of mammary gland involution. Proc. Natl. Acad. Sci. USA 94:3425-3430.

Li, P., P. S. Rudland, D. G. Fernig, L. M. Finch, and C. J. Wilde. 1999. Modulation of mammary development and programmed cell death by the frequency of milk removal in lactating goats. J. Physiol. 519:885-900.

Liu, X., G. W. Robinson, K. U. Wagner, L. Garrett, A. WynshawBoris, and L. Hennighausen. 1997. StatSa is mandatory for adult mammary gland development and lactogenesis. Genes Dev. 11:179-186.

Mallah, G. S., J. Dobson, S. Moon, H. V. Henderson, A. Molenaar, J. Guan, and K. Singh. 2013. The effect of re-milking following extended non-milking periods on the proliferation and apoptosis of mammary epithelial cells in dairy cows. Proc. N.Z. Soc. Anim. Prod. 73:51-53.

Matsuda, M., T. Imaoka, A. J. Vomachka, G. A. Gudelsky, Z. Hou, M. Mistry, J. P. Bailey, K. M. Nieport, D. J. Walther, M. Bader, and N. D. Horseman. 2004. Serotonin regulates mammary gland development via an autocrine-paracrine loop. Dev. Cell 6:193-203.

Mead, P. E., and J. W. Tweedie. 1990. cDNA and protein sequence of bovine lactoferrin. Nucleic Acids Res. 18:7167.

Millier, M. J., K. Singh, and C. A. Poole. 2013. Characterization of primary cilia distribution and morphology during lactation, stasis, and involution in the bovine mammary gland. Anat. Rec. (Hoboken) 296:1943-1953.

Molenaar, A. J., S. R. Davis, and R. J. Wilkins. 1992. Expression of alpha-lactalbumin, alpha-S1-casein, and lactoferrin genes is heterogeneous in sheep and cattle mammary tissue. J. Histochem. Cytochem. 40:611-618.

Molenaar, A. J., D. P. Harris, G. H. Rajan, M. L. Pearson, M. R. Callaghan, L. Sommer, V. C. Farr, K. E. Oden, M. C. Miles, R. S. Petrova, L. L. Good, K. Singh, R. D. McLaren, C. G. Prosser, K. S. Kim, R. J. Wieliczko, M. H. Dines, K. M. Johannessen, M. R. Grigor, S. R. Davis, and K. Stelwagen. 2009. The acute-phase protein serum amyloid A3 is expressed in the bovine mammary gland and plays a role in host defence. Biomarkers 14:26-37.

Molenaar, A. J., Y. M. Kuys, S. R. Davis, R. J. Wilkins, P. E. Mead, and J. W. Tweedie. 1996a. Elevation of lactoferrin gene expression in developing, ductal, resting, and regressing parenchymal epithelium of the ruminant mammary gland. J. Dairy Sci. 79:1198-1208

Molenaar, A. J., R. J. Wilkins, and S. R. Davis. 1996b. Measurement of cell death by in situ end labelling of ruminant mammary gland tissue. Proc. N.Z. Soc. Anim. Prod. 56:71-76.

Murney, R., K. Stelwagen, T. T. Wheeler, J. K. Margerison, and K. Singh. 2015. Activation of signal transducer and activator of transcription 5 (STAT5) is linked to $\beta 1$-integrin protein abundance in unilaterally milked bovine mammary glands. J. Dairy Sci. 98:3133-3142

Oliver, S. P., and L. M. Sordillo. 1989. Approaches to the manipulation of mammary involution. J. Dairy Sci. 72:1647-1664.

Philp, J. A. C., T. G. Burdon, and C. J. Watson. 1996. Differential activation of STATs 3 and 5 during mammary gland development. FEBS Lett. 396:77-80.

Phyn, C. V. C., J. M. Dobson, S. R. Davis, K. Stelwagen, and K. Singh. 2007. Induced physical distension of rat mammary glands accelerates the onset of apoptosis and involution compared with milk accumulation alone. Proc. N.Z. Soc. Anim. Prod. 67:403-406.

Schmitt-Ney, M., B. Happ, P. Hofer, N. E. Hynes, and B. Groner 1992. Mammary gland-specific nuclear factor activity is positively regulated by lactogenic hormones and negatively by milk stasis. Mol. Endocrinol. 6:1988-1997. 
Shamay, A., F. Shapiro, G. Leitner, and N. Silanikove. 2003. Infusions of casein hydrolyzates into the mammary gland disrupt tight junction integrity and induce involution in cows. J. Dairy Sci. $86: 1250-1258$.

Shorten, P. R., I. Vetharaniam, T. K. Soboleva, G. C. Wake, and S. R. Davis. 2002. Influence of milking frequency on mammary gland dynamics. J. Theor. Biol. 218:521-530.

Singh, K., S. R. Davis, J. M. Dobson, A. J. Molenaar, T. T. Wheeler, C. G. Prosser, V. C. Farr, K. Oden, K. M. Swanson, C. V. Phyn, D. L. Hyndman, T. Wilson, H. V. Henderson, and K. Stelwagen. 2008. cDNA microarray analysis reveals that antioxidant and immune genes are upregulated during involution of the bovine mammary gland. J. Dairy Sci. 91:2236-2246.

Singh, K., J. Dobson, C. V. C. Phyn, S. R. Davis, V. C. Farr, A. J. Molenaar, and K. Stelwagen. 2005. Milk accumulation decreases expression of genes involved in cell-extracellular matrix communication and is associated with induction of apoptosis in the bovine mammary gland. Livest. Prod. Sci. 98:67-78.

Singh, K., K. M. Swanson, H. V. Henderson, R. A. Erdman, and K. Stelwagen. 2015. The effect of milking reinitiation following extended non-milking periods on lactation in primiparous dairy cows. J. Dairy Sci. 98:7666-7674.

Singh, K., I. Vetharaniam, J. M. Dobson, M. Prewitz, K. Oden, R. Murney, K. M. Swanson, R. McDonald, H. V. Henderson, and K. Stelwagen. 2016. Cell survival signaling in the bovine mammary gland during the transition from lactation to involution. J. Dairy Sci. 99:7523-7543.

Sordillo, L. M., and S. C. Nickerson. 1988. Morphologic changes in the bovine mammary gland during involution and lactogenesis. Am. J. Vet. Res. 49:1112-1120.
Sorensen, M. T., J. V. Norgaard, P. K. Theil, M. Vestergaard, and K. Sejrsen. 2006. Cell turnover and activity in mammary tissue during lactation and the dry period in dairy cows. J. Dairy Sci. 89:4632-4639.

Stelwagen, K. 2001. Effect of milking frequency on mammary functioning and shape of the lactation curve. J. Dairy Sci. 84(E. Suppl.):E204-E211.

Stelwagen, K., V. C. Farr, S. R. Davis, and H. A. McFadden. 1998. Inhibition of milk secretion and the extent of filling of the bovine mammary gland. J. Dairy Sci. 81(Suppl. 1):376.

Stewart, A. F., I. M. Willis, and A. G. Mackinlay. 1984. Nucleotide sequences of bovine alpha S1- and kappa-casein cDNAs. Nucleic Acids Res. 12:3895-3907.

Vetharaniam, I., S. R. Davis, T. K. Soboleva, P. R. Shorten, and G. C. Wake. 2003a. Modeling the interaction of milking frequency and nutrition on mammary gland growth and lactation. J. Dairy Sci. $86: 1987-1996$

Vetharaniam, I., S. R. Davis, M. Upsdell, E. S. Kolver, and A. B. Pleasants. 2003b. Modeling the effect of energy status on mammary gland growth and lactation. J. Dairy Sci. 86:3148-3156.

Wheeler, T. T., M. K. Broadhurst, H. B. Sadowski, V. C. Farr, and C. G. Prosser. 2001. Stat5 phosphorylation status and DNA-binding activity in the bovine and murine mammary glands. Mol. Cell. Endocrinol. 176:39-48.

Wilde, C. J., C. Addey, P. Li, and D. Fernig. 1997. Programmed cell death in bovine mammary tissue during lactation and involution. Exp. Physiol. 82:943-953.

Wilde, C. J., C. H. Knight, and D. J. Flint. 1999. Control of milk secretion and apoptosis during mammary involution. J. Mammary Gland Biol. Neoplasia 4:129-136. 